\title{
Expression and embryonic function of empty spiracles: a Drosophila homeo box gene with two patterning functions on the anterior-posterior axis of the embryo
}

\author{
Dyana Dalton,, ${ }^{1,3}$ Robin Chadwick, ${ }^{2,4}$ and William McGinnis ${ }^{2}$ \\ ${ }^{1}$ Departments of Human Genetics and ${ }^{2}$ Molecular Biophysics and Biochemistry, Yale University, New Haven, Connecticut \\ 06511 USA
}

\begin{abstract}
Using the even-skipped homeo box as a probe to identify diverged homeo box genes in the Drosophila genome, we isolated the empty spiracles (ems) gene. Structural and functional comparisons between ems and other embryonic patterning genes of Drosophila suggest that ems acts, in part, as a homeotic selector gene, specifying the identity of some of the most anterior head segments. Mutant embryos lacking ems protein have severe patterning defects in the anterior head and are missing tracheal structures, including the filzkörper, which are normally developed by the eighth abdominal segment. ems has two different spatial patterns of expression during embryogenesis. The early, head-specific pattern consists of a single anterior stripe at the syncytial and cellular blastoderm stages. The later, metameric pattern consists of bilateral patches of ems expression in neural and ectodermal cells of every head and body segment. Variations of the ems expression pattern in bicoid mutants suggests that the morphogen protein produced by bicoid has a concentration-dependent regulatory role in the establishment of head-specific ems expression. In contrast, the metameric ems pattern is initiated independently of bicoid protein, and ems becomes expressed at high levels in the primordia of the duplicated filzkörper that develop in the anterior half of bicoid mutant embryos.
\end{abstract}

[Key Words: Drosophila; empty spiracles; homeo box; pattern formation]

Received April 20, 1989; revised version accepted September 25, 1989.

Most of the genes required for spatial patterning on the anterior-posterior (AP) axis of the Drosophila embryo have been identified in genetic screens for mutations that result in cuticular defects. Analysis of these genes and their interactions has led to a tentative model of embryonic patterning on the AP axis. Establishment of overall AP polarity requires the expression of maternal coordinate genes (Frohnhöfer et al. 1986; MacDonald and Struhl 1986; Schüpbach and Wieschaus 1986; Nüsslein-Volhard et al. 1987; Berleth et al. 1988). The metameric pattern of the embryo is then established by three classes of segmentation genes. The gap genes, the pairrule genes, and the segment polarity genes divide the embryo into successively more discrete domains, resulting in segmentation (Nüsslein-Volhard and Wieschaus 1980; for review, see Akam 1987). Finally, the homeotic selector genes, most of which are found in the Antennapedia and Bithorax complexes, are required to assign unique identities to the segments (Lewis 1978; Kaufman 1983).

${ }^{3}$ Current address: Genentech, Department of Developmental Biology, South San Francisco, California 94080 USA.; ${ }^{4}$ Department of Brain and Cognitive Science, Massachusetts Institute of Technology, Cambridge, Massachusetts 02139 USA.
Many of the Drosophila embryonic patterning genes are members of multigene families that share conserved protein-coding regions (McGinnis et al. 1984b; Frigerio et al. 1986). Thus, a method to isolate cloned copies of potential embryonic patterning genes has been to use these conserved protein-coding regions as probes to isolate and identify additional family members. This approach has been exploited most productively with the use of a conserved 180-bp DNA sequence called the homeo box, which has identified the coding regions of many previously known Drosophila patterning genes (McGinnis et al. 1984a; Scott and Weiner 1984; Levine et al. 1985) and at least one previously unidentified patterning gene, caudal (Mlodzik et al. 1985; McDonald and Struhl 1986). Homeo box sequences encode amino acid domains of $\sim 60$ residues called homeo domains, which are part of proteins that range in size from $\sim 25$ to $75 \mathrm{kD}$. All homeo domains tested to date contain a sequence-specific DNA binding activity (Desplan et al. 1985, 1988; Hoey and Levine 1988; for review, see Scott et al. 1989|. The DNA-binding and transcriptional regulatory functions encoded in Drosophila homeo domain proteins (Han et al. 1989; Jaynes and O'Farrell 1988; Driever and Nüsslein-Volhard 1989; Krasnow et al. 
Structure and function of empty spiracles

1989; Winslow et al. 1989/ are believed to be the principal biochemical mechanisms through which homeo box genes assign cell, segmental, or regional fate.

Because the homeo box is found in many developmental patterning genes, we have been isolating divergent members of the Drosophila homeo box gene family with the expectation that some may control additional developmental patterning functions. For example, several known homeotic selector genes assign unique segmental identities to thoracic and abdominal regions on the AP axis. However, no known selectors would assign the diverse head segment identities anterior to those assigned by Deformed (Dfd) and labial (Merrill et al. 1987; Regulski et al. 1987; Diederich et al. 1989). As is described here, one of the divergent homeo box genes that has been isolated, empty spiracles (ems), is required for the development of structures that derive from some of the most anterior head segments of the Drosophila embryo. In addition, ems is required for development of the tracheal system in the eighth abdominal segment. Comparisons with other patterning genes lead us to propose that the principal embryonic role of ems is to act as a homeotic selector gene controlling antennal and mandibular segment identity.

\section{Results}

Genomic library screen with the even-skipped homeo box probe

To test whether the even-skipped (eve) homeo box could detect more divergent members of the homeo box gene family, we hybridized an eve homeobox probe to a Southern blot of EcoRI-digested Drosophila genomic DNA. Under reduced stringency conditions, multiple EcoRI fragments in the Drosophila genome hybridize the eve homeo box probe. Most of the hybridizing fragments differ in size from the EcoRI fragments, representing previously isolated homeo box genes (data not shown), suggesting that they contain new members of the Drosophila homeo box family.

To isolate clones containing these new homeo boxes, a Drosophila genomic library was screened under reduced stringency conditions with the eve homeo box probe. A total of 81 phage clones were isolated and separated into 12 different classes, based on high-stringency hybridization to each other and to previously isolated homeo box genes. Five of the classes correspond to the previously isolated homeo box genes eve, Sex combs reduced (Scr), labial, H2.0, and bicoid (bcd) (Kuroiwa et al. 1985; MacDonald et al. 1986b; Frasch et al. 1987; Barad et al. 1988; Berleth et al. 1988; Diederich et al. 1989). The remaining seven classes, designated E4, E5, E81, E86, E97, E103, and E111, represent new Drosophila homeo box sequences mapping to the cytogenetic locations shown in Table 1.

The new homeo box genes were initially characterized by testing the temporal and spatial expression of their transcripts during embryogenesis. We were particularly interested in any with potential roles in anterior head
Table 1. Cytological locations of the new homeo box clones

\begin{tabular}{lc}
\hline Clone & Cytological location \\
\hline E4 & $88 \mathrm{Al}, 2$ \\
E5 & $88 \mathrm{~A}$ \\
E81 & $69 \mathrm{C} / \mathrm{D}$ \\
E86 & $38 \mathrm{~A} 1-3$ \\
E97 & $57 \mathrm{~B} 5,6$ \\
E103 & $90 \mathrm{~F}$ \\
E111 & $73 \mathrm{~A}$ \\
\hline
\end{tabular}

development. As is described in more detail below, the E4 homeo box clone detects transcripts and proteins at the cellular blastoderm that are localized in a stripe in the primordia of the anterior head. A mutant with defective head development, ems, had been mapped previously to roughly the same cytogenetic position as E4 (Jürgens et al. 1984). These initial results suggested that the E4 homeo box clone might encode ems. To test this possibility, we performed a detailed molecular analysis of the E4 homeo box gene in wild-type chromosomes, as well as in ems mutant chromosomes.

\section{Cytological location of the E4 clone}

The cytological location of E4 was found to be within the $88 \mathrm{Al}, 2$ doublet by in situ localization of a biotinylated E4 probe in polytene chromosome preparations. Several deficiency chromosomes with breakpoints in the $88 \mathrm{~A}$ region were used to provide a more detailed cytogenetic localization for both $\mathrm{E} 4$ sequences and ems mutant alleles. The deficiency chromosomes were first tested by in situ hybridization for the presence or absence of E4 DNA sequences on the deleted chromatid. Deficiency chromosomes were also placed in trans to recessive lethal ems alleles to determine whether each deficiency uncovered the ems gene. The deficiency chromosomes $D f(3 R) r y^{85}$ (Hall and Kankel 1976) and $D f(3 R) r^{p 52}$ (Capdevila and Garcia-Bellido 1981; R. Kelley, pers. comm.), with breakpoints at 88A1 and 88A4, respectively, contain E4 DNA sequences and do not uncover the ems mutants (Fig. 1). The deficiency chromosomes $D f(3 R) f s 293^{\gamma 5}$ (R. Kelley, pers. comm.), $D f(3 R)$ red $^{1}$ (Gans et al. 1980; R. Kelley, pers. comm.), and $D f(3 R)$ red $^{31}$ (Hall and Kankel 1976), which have deletions that eliminate the $88 \mathrm{~A} 1-88 \mathrm{~A} 4$ region, are all missing E4 sequences and all uncover the ems mutations. These results place both the E4 sequences and the ems gene in the cytogenetic interval 88A1-88A4 (Fig. 1).

\section{Molecular structure of the E4 locus}

The eve homeo box screen of a $\lambda \mathrm{EMBL} 4$ library led to the isolation of a $14-\mathrm{kb} E 4$ genomic insert in the clone $\lambda E 4$, shown in Figure 2A. To test the number of transcript species that include the $\mathrm{E} 4$ homeo box, a $4.1-\mathrm{kb}$ EcoRI-HindIII fragment, which contains the homeo box exon of the E4 transcription unit, was hybridized to a 
Figure 1. Cytogenetic location of E4 and of mutant alleles of ems. Location of the E4 clone and of ems mutant alleles with respect to breakpoints in the $88 \mathrm{~A}$ region. A biotin-labeled E4 probe was hybridized to polytene chromosome preparations from wild-type and deficiency stocks. The chromosomes were scored for the absence $\left(\mathrm{E}^{-}\right)$or presence $\left(\mathrm{E} 4^{+}\right)$of a hybridization signal. The arrow indicates the $88 \mathrm{Al}, 2$ doublet that the E4 clone normally hybridizes. Each deficiency chromosome was also placed in trans to an ems mutant chromosome, and embryos were examined for the recessive lethal ems phenotype (ems-) or a normal phenotype $\left(e m s^{+}\right)$.

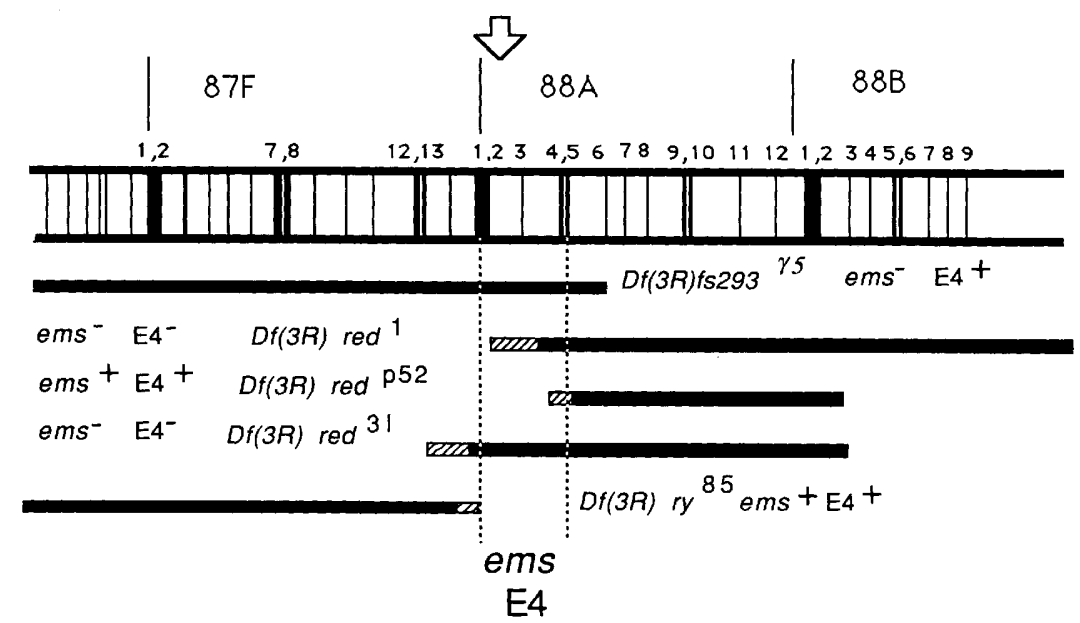

was determined. A comparison of the sequence of the cDNA with a partial sequence of the genomic DNA indicates that the transcription unit of $\mathrm{E} 4$ contains an intron of $\sim 300$ bp just upstream of the homeo box. The $5^{\prime}$ end of the intron occurs between two PvuII sites, which are $120 \mathrm{bp}$ apart in the cDNA and $410 \mathrm{bp}$ apart in the genomic DNA (Fig. 2A). The complete sequence of the intron was not determined. The pE4 cDNA12 insert terminates in the $3^{\prime}$-untranslated region at an EcoRI site that is present in the genomic DNA. The $3^{\prime}$-terminal sequences of the cDNA were presumably lost by EcoRI digestion during the construction of the cDNA library.

\section{The predicted protein of the E4 transcription unit}

The longest open reading frame (ORF) of pE4cDNA12 contains a homeo box and extends over 1482 bp (Fig. 3A). The first methionine codon of this reading frame occurs at nucleotide residue 293 in the context 5 '-ATTTATG-3'. The sequence flanking this ATG codon bears
A

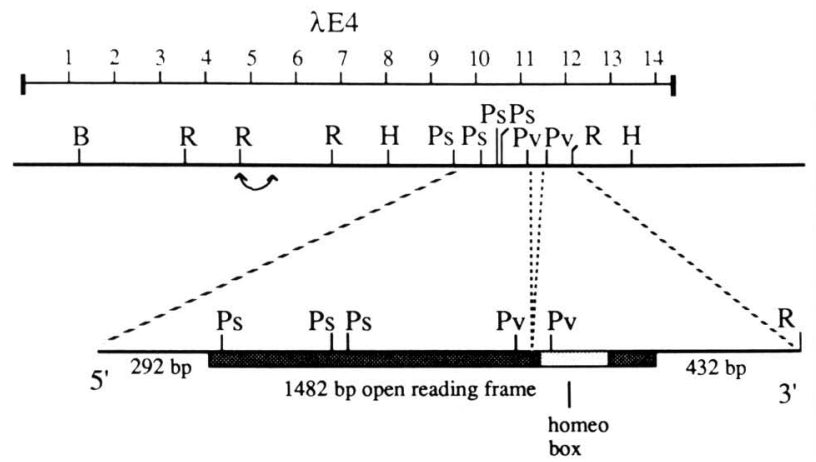

B
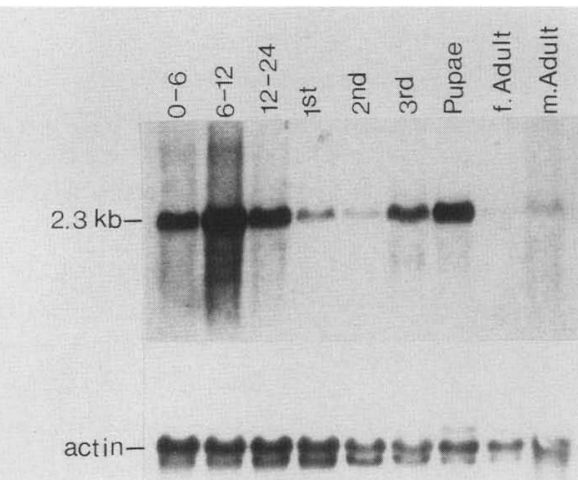

Figure 2. The E4/ems transcription unit. $(A)$ Molecular structure of the E4 genomic phage clone and the E4 transcription unit. The cDNA (not drawn to scale) is shown below a restriction map of the phage clone. The dashed lines indicate the position of an intron, between the Pvull sites, which is spliced out of the cDNA. $(B)$ Northern analysis of E4 expression throughout the Drosophila life cycle. Poly(A) RNA from 0- to 6-, 6- to $12-$, and $12-$ to $24-\mathrm{hr}$ embryos, as well as first (1 $\left.{ }^{\text {st }}\right)$, second $\left(2^{\text {nd }}\right)$, and third $\left(3^{\text {rd }}\right)$ instar larvae, pupae, and male and female adults, was electrophoretically resolved on a formaldehyde-agarose gel, blotted onto nitrocellulose, and hybridized with a ${ }^{32} \mathrm{P}$-labeled 4.1-kb EcoRI-HindIII genomic DNA fragment containing the E4 transcription unit. The same blot was hybridized with an actin probe to estimate the relative amount of RNA loaded into each lane. 


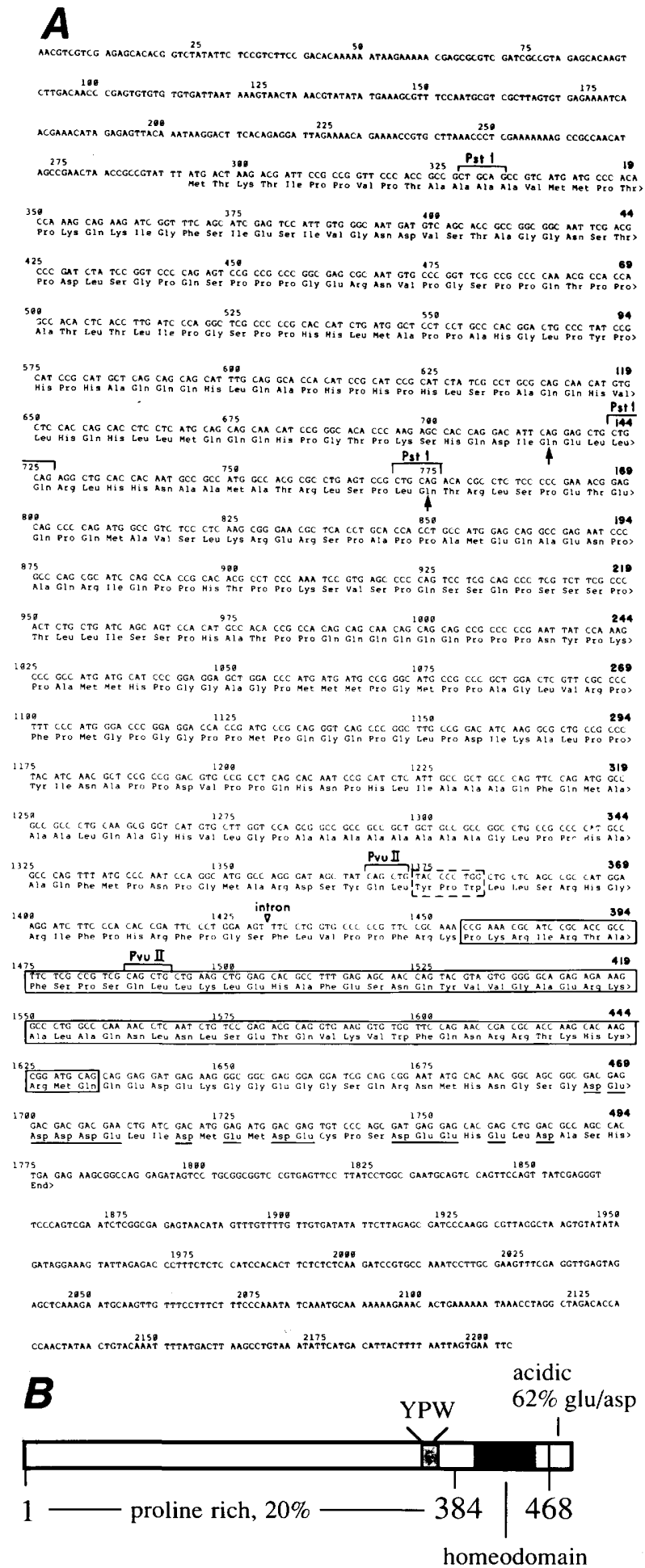

Figure 3. Nucleotide and predicted amino acid sequence of the E4/ems cDNA. (A) The 2207-bp sequence includes $293 \mathrm{bp}$ of 5 '-untranslated and $433 \mathrm{bp}$ of 3 '-untranslated DNA. The predicted protein is 494 amino acids. The homeo domain is boxed with a solid line. The Leu-Tyr-Pro-Trp sequence is boxed with a dashed line. The acidic residues in the carboxy-terminal acidic region are underlined. Arrows indicate the positions of the glutamine residues that are mutated to termination codons in the ems mutants. The position of an intron is indicated. (B) A schematic diagram of the predicted E4/ems protein. only a slight resemblance to the Drosophila translational start site consensus sequence C/A AA A/ C ATG of Cavener (1987). If translation begins at this first in-frame methionine codon, the ORF would encode a protein of 494 amino acid residues.

The 494-amino-acid E4 protein has several interesting features. A schematic diagram of the predicted protein is shown in Figure 3B. The first four-fifths of the predicted protein, extending from amino acid residue 1 to 384 , contains 80 proline residues, resulting in a remarkably high proline content of $20 \%$. A glutamine-rich region, extending from amino acid residue 99 to 359 , contains 32 glutamine residues, resulting in a glutamine content of $12 \%$. The relatively high glutamine content is a result of an enrichment of CAG/A sequences in this part of the coding region. These repeated sequences, variously designated as CAX, M-repeat, or opa, are found in the coding regions of many developmentally important genes (Poole et al. 1985; Regulski et al. 1985; Wharton et al. 1985). In the E4-coding region, the CAX sequences are interspersed among the other codons with the longest stretch being six glutamine codons in a row. Another repeated amino acid is found in the short stretch of eight alanine residues between amino acids 330 and 339 (Fig. 3). The sequence Leu-Tyr-Pro-Trp-Leu, located 28 amino acids upstream of the $\mathrm{E} 4$ homeo box, matches four of the conserved residues of a pentapeptide sequence, Ile/Leu-Tyr-Pro-Trp-Met, which appears in a similar position in the Drosophila homeotic selector proteins $D f d$, Antp, Scr, and Ubx (Mavilio et al. 1986; Schneuwly et al. 1986; Regulski et al. 1987; Weinzierl et al. 1987; LeMotte et al. 1989). A region of acidic amino acids occurs at the carboxyl terminus of the predicted E4 protein. In a stretch of 24 amino acid residues, 15 (62\%) are acidic (Fig. 3). A search of the NBRF and the PSEQIR protein data bases did not reveal any other extended amino acid sequence matches with the predicted E4 protein beyond the expected homeo domain matches and some small regions of identity within the polyalanine and polyglutamine sequences.

The E4 homeo domain is quite divergent from other homeo domains, as it shares $50 \%$ or fewer of its amino acid residues with all other published homeo domains. The best match is found in the E5 transcription unit, another of the newly isolated homeo box genes listed in Table 1. The E4 and E5 homeo domain sequences are identical at 52 of 60 amino acid residues (Fig. 4). The E5 homeo box sequence maps to the same cytogenetic interval as E4, but overlapping clones that would link the E4 and E5 loci have not yet been isolated. E5 transcripts

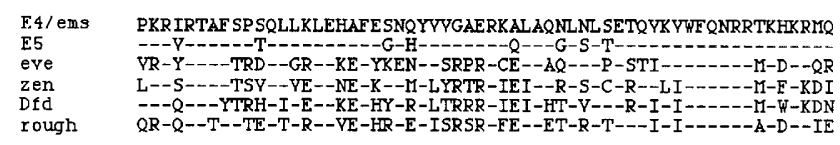

Figure 4. The E4/ems homeo domain sequence compared to the homeo domain sequences from E5 (Table 1), eve (Frasch et al. 1987; MacDonald and Struhl 1986), zen (Rushlow et al. 1987), Dfd (Regulski et al. 1987), and rough (Saint et al. 1988; Tomlinson et al. 1988). 
are not expressed at early stages of embryogenesis but are distributed in a metameric pattern that partially overlaps the E4 expression pattern at later stages of embryogenesis (described later in text).

\section{The E4 transcription unit encodes ems}

Both the cytological location and the expression pattern of the E4 transcripts suggested that E4 might encode ems. To test this hypothesis, we analyzed the DNA of ems mutants for changes in the $\mathrm{E} 4$ protein-coding sequence, using restriction mapping and DNA sequencing.

First, we compared the E4 restriction maps from a parental stock and the ems mutant alleles designated $e m s^{7 D}, e m s^{9 H}$, and $e m s^{9 Q}$. One difference is seen at this level in the genomic Southern blot of ems mutant DNAs shown in Figure 5A. An extra EcoRI-PstI fragment of $1.77 \mathrm{~kb}$, which is $\sim 50 \mathrm{bp}$ larger than the normal $1.72-\mathrm{kb}$ EcoRI-PstI fragment, is present in $e m s^{9 H}$ DNA. The restriction map of the E4 transcription unit suggested that the new fragment could result from the absence of the $3^{\prime}$ PstI site (marked by an asterisk in Fig. 5B) in the $e m s^{9 H}$ mutant. Digestion at the PstI site, 48 bp upstream of the missing site, would generate the slightly larger EcoRIPstI fragment. To determine the nucleotide sequence around the presumptively mutated PstI site, a $5.4-\mathrm{kb}$ EcoRI fragment containing the $\mathrm{E} 4$ transcription unit was isolated from the $e m s^{9 H}$ mutants. Sequence analysis revealed that a $\mathrm{GC} \rightarrow \mathrm{AT}$ transition mutation within the PstI site has converted a glutamine codon in the E4 ORF to a termination codon (CAG $\rightarrow$ TAG; see Fig. $5 B \mid$. This mutation results in a premature termination of the predicted E4 protein at amino acid residue 161 and also eliminates the PstI recognition sequence.

A 5.4-kb EcoRI fragment containing the E4 proteincoding sequences was isolated from a second mutant, $e m s^{9 Q}$. Sequence analysis of this fragment revealed another mutation of a CAG glutamine codon to a TAG termination codon at a different position in the $\mathrm{E} 4$ protein- coding sequence (Fig. 5B). This ems mutation would result in a premature termination of the predicted E4 protein at amino acid residue 141 . The preceding results provide convincing evidence that the E4 homeo-boxcontaining transcription unit corresponds to the ems gene. The crucial evidence for the correspondence of E4 and ems is that the sequence of the E4 ORF derived from two different mutant alleles of ems contains mutated codons that would result in the premature termination of the predicted E4 protein. We will hereafter refer to the E4 transcription unit as ems.

\section{The ems mutant phenotype}

Five recessive mutant alleles of the ems gene were obtained by Jürgens et al. (1984) in a search for zygotic patterning mutations. The gene derives its name from a defect in the tracheal system of ems mutants. Normally the posterior spiracles (breathing ports) of the larva contain filzkörper, which are filters lining the tracheal tubes in the posterior spiracles. The filzkörper are missing from the ems mutant embryos (Jürgens et al. 1984; Fig. $6 \mathrm{D}, \mathrm{E})$. Jürgens et al. (1984) also noted that the antennal sense organs were absent from the mutants, which died without emerging from the eggshell at the end of embryogenesis.

To gain more insight into the role of ems in embryonic development, we performed a detailed analysis of the cuticular phenotype of both null and hypomorphic alleles of ems. For the null phenotype, embryos of the genotype ems $s^{9 H} / D f(3 R) r_{e} d^{3 I}$ were examined. The $e m s^{9 H}$ allele has a premature termination codon at amino acid residue 161 (Fig. 5), and no detectable ems protein is present in the $e m s^{9 H}$ homozygotes (data not shown). The deficiency chromosome $D f(3 R)$ red $^{3 I}$ has a deletion of the ems locus (Jürgens et al. 1984; Fig. 1). Cleared cuticular preparations (Wieschaus and Nüsslein-Volhard, 1986) of terminally differentiated ems embryos were used to analyze the mutant morphology.

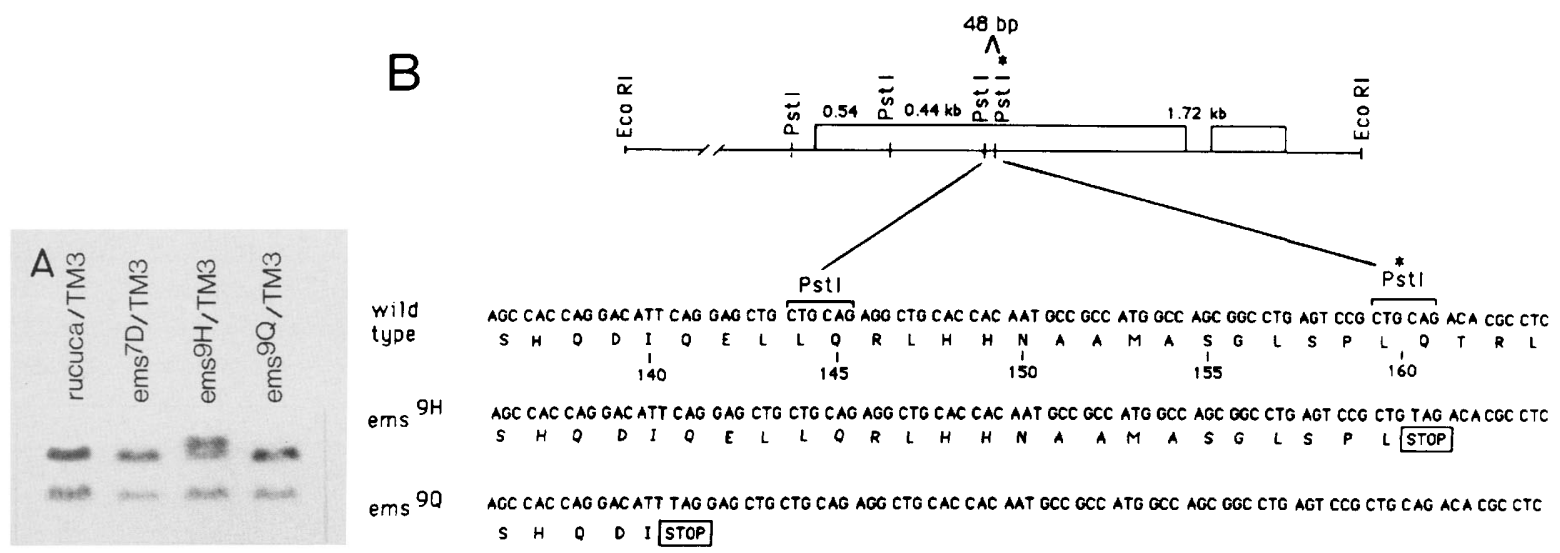

Figure 5. Termination codons in E4 protein-coding sequence in ems mutants. $(A)$ Southern blot of ems ${ }^{-}$genomic DNA hybridized with the E4 cDNA probe. The fly strain rucuca/TM3 carries the rucuca chromosome, which is the parental chromosome for the ems mutants. $e m s^{9 H}, e m s^{9 Q}$, and $e m s^{7 D}$ are three different alleles of ems. All of the mutant chromosomes are balanced with the TM3 chromosome. Complete genotypes are given in Materials and methods. $(B)$ Restriction map and partial sequence of the E4-coding region from two ems mutants. The PstI site, which is missing in the $e m s^{9 H}$ mutant, is marked with an asterisk $\left({ }^{\star}\right)$. The positions of the termination (stop) codons are indicated in the sequences of $e m s^{9 Q}$ and $e m s^{9 H}$. 


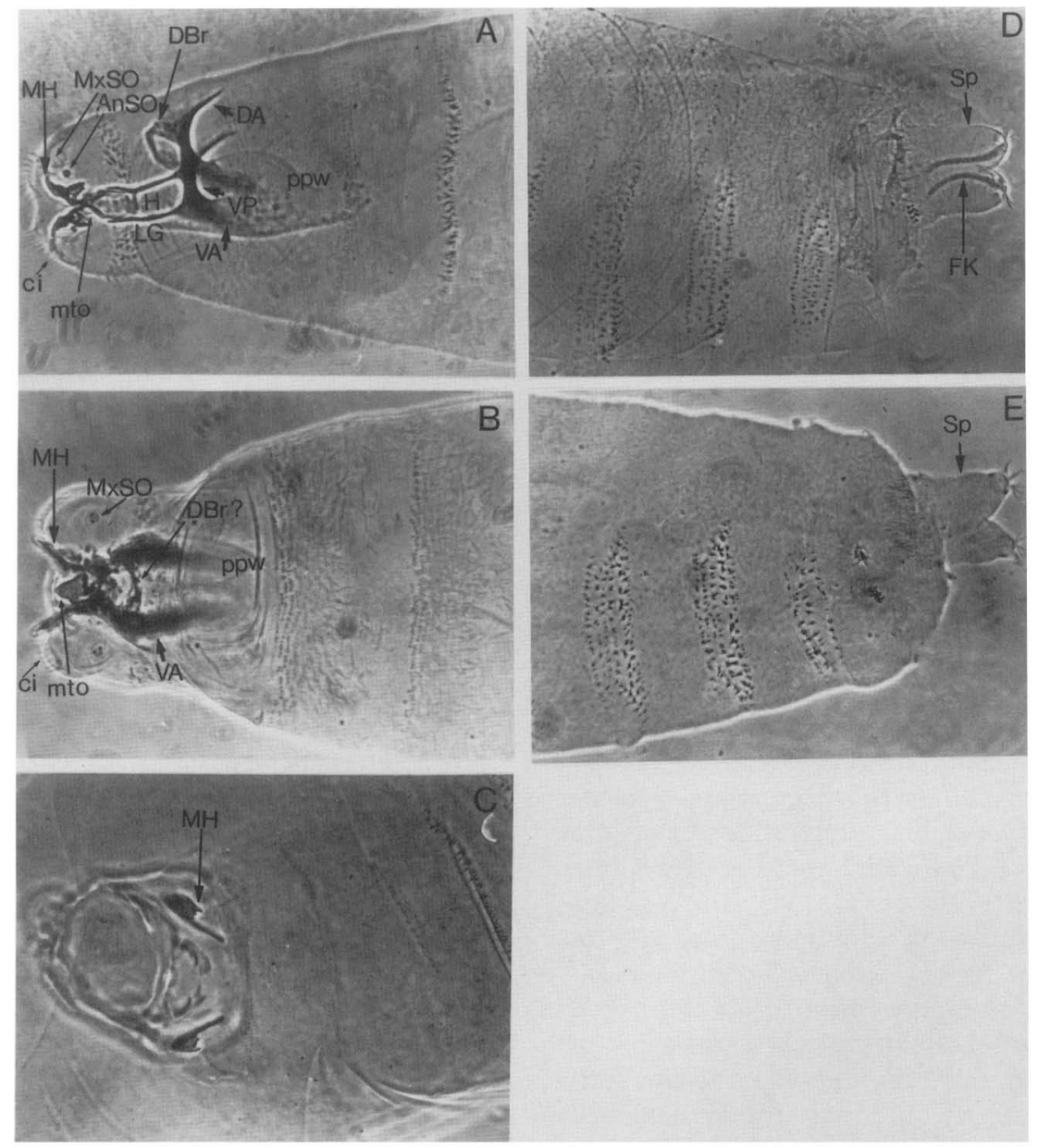

Figure 6. Cuticular preparations of wild-type and ems mutant embryos. (A) Wild-type cuticular head structures. $(B)$ The ems ${ }^{10 A}$ mutant with an involuted head. Structures that are present are labeled, (for the normal location of missing structures, cf. with $A),(C)$ An $e m s^{9 H} / D f(3 R) r^{2} d^{3 I}$ null mutant with an open head. Only the mouth hooks are labeled, although cirri, maxillary sense organs, and other structures are visible in other planes of focus. $(D)$ Wild-type posterior spiracles with tracheal tubes and filzkörper. $\{E \mid$ ems mutant posterior spiracles. The tracheal tubes are absent from the spiracles. (MH) mouth hooks; (ci) cirri; (MxSO) maxillary sense organs; (mto) median tooth; (AnSO) antennal sense organs; (H) cross piece of H-piece; (LG) lateralgräten; (DBr) dorsal bridge; (VA) ventral arms; (VP) vertical plates; (DA) dorsal arms; (ppw) posterior wall of the pharynx; (Sp) spiracles; (FK) filzkörper.

During normal Drosophila embryonic development, the six lobes of the head (clypeolabral, procephalic, hypopharyngeal, mandibular, maxillary, and labiall migrate through the stomodeal opening during the process of head involution (for a complete description, see Turner and Mahowald 1979). Once involuted, the ectodermal cells of the head lobes secrete the cuticular and sensory structures of the head, which include the cephalopharyngeal or head skeleton, median tooth, mouth hooks, antennal and maxillary sense organs, and cirri (Jürgens et al. 1986; Fig. 6A). The normal morphology of several of these structures depends on the fusion and correct juxtaposition of the internalized head lobes. In the null ems mutant embryos, the process of head involution fails, but some of the skeletal and sensory structures are still secreted by the noninvoluted head lobes.

There appear to be no changes in the cuticular structures of the labial segment in ems null mutant embryos compared to the labial structures of embryos with head involution defects (Struhl 1983; Gibson and Gehring 1988). The maxillary segment also appears to be largely normal, with the mouth hooks and cirri still present (Fig. 6C). Similarly, the clypeolabral segment appears relatively normal, as the median tooth is present in the ems null mutant embryos. The structures obviously missing are the antennal sense organs, a pair of domeshaped sensory organs originating from the antennal segment, and the vertical plates of the head skeleton (Fig. 6A,C).

The head skeleton and associated structures are secreted on the inside of the head in $-20 \%$ of homozygotes for the hypomorphic allele, ems ${ }^{10 A}$. This makes $e m s^{10 A}$ advantageous for a detailed analysis of the ems mutant phenotype, because it is possible to see the presence or absence of head structures in embryos that have undergone at least partial head involution. The remaining $80 \%$ of the $10 \mathrm{~A}$ mutants have a phenotype very similar to the null mutant. 
Several of the elements that form the head skeleton are missing in the $e m s^{\wedge \circ \wedge}$ hypomorph. The dorsal part of the head skeleton is composed of a pair of dorsal arms that are connected by the dorsal bridge (Fig. 6A). These structures are attached to the ventral part of the head skeleton by the vertical plates. The vertical plates attach to the lateralgraten anteriorly and to the ventral arms posteriorly. The ems mutant embryo is missing both the dorsal arms and the vertical plates (Fig. 6B). A dorsal bridge is present but has a fragmented appearance. All of these structures are normally specified by the procephalic lobe cells of the embryonic head. Other head structures missing in the $e$ in $s^{\wedge \circ \wedge}$ mutant include the lateral bars of the H-piece and the lateralgraten. The lateralgraten are derived from the mandibular segment, whereas the H-piece is of mixed segmental origin and seems particularly sensitive to defects in head involution (Jiirgens et al. 1986).

The eni ${ }^{\wedge \wedge \wedge}$ mutant is also missing both of the sensory structures that derive from the antennal segment, the antennal sense organs, and the dorsomedial papillae (DMP) (Jurgens et al. 1986). The DMP are peripheral papillae that are associated with the maxillary sense organs in the mature larvae epidermis. In addition, the dorsolateral papillae (DLP), derived from the mandibular segment (Jurgens et al. 1986), are absent in the ems mutant. In summary, the head defects in em.s null and hypomorphic mutants consist of loss of many of the cuticular structures that normally derive from the procephalic and mandibular lobes of the head (for a diagram of the head lobes, see Fig. 9). The procephalic lobe includes the primordia of both the antennal segment and the acron (the most anterior nonsegmented region of the Diosophila body plan).

The only other morphological defect that we observed in either cleared cuticle preparations or whole mounts of terminal ems mutant embryos is the loss of the filzkorper in the posterior spiracles of the tracheal system. The longitudinal trunks of the tracheal tree normally connect to the exterior via the posterior spiracles (Poulson 1950). Whole-mount preparations of the ems mutants reveal not only that the spiracles are empty but also that the posterior ends of the longitudinal trunks are missing. The termini of the longitudinal trunks float freely in the posterior abdominal cavity, unattached to the posterior spiracles.

\section{ems Protein and production of antibodies}

To obtain ems protein for antibody production, the ems cDNA, containing the coding region for amino acids 11-494, was subcloned into the T7 expression vector pAR3038 (Studier and Moffatt 1986), as described in Materials and methods. The $60-\mathrm{kD}$ protein produced from the expression vector was partially purified and injected into rabbits for polyclonal antibody production. The ems antiserum obtained from rabbits was used to stain embryos from the balanced stocks $e m s^{\wedge \wedge} / T M S$ and $e m s^{\wedge \wedge} l$ TM3. The mutants $e m s^{\wedge \wedge}$ and $e m s^{\wedge \wedge}$ have premature termination codons at amino acid residues 161 and 141, re- spectively. One-fourth of the embryos collected from these stocks failed to stain with the ems antibody, consistent with the specific detection of protein from the ems locus.

\section{ems head-specific expression pattern}

The ems protein is expressed in two independently regulated patterns that are initiated at different times and have different, but overlapping, spatial distributions. The ems head-specific expression pattern initiates prior to cellular blastoderm and continues only until early germ-band extension. The ems metameric expression pattern initiates after gastrulation and is expressed in the lateral neuroblasts, in ectodermal cells at the anterior lateral borders of each segment, and in the filzkorper primordia. As will be discussed in more detail below, the head and metameric patterns overlap in the procephalic and mandibular lobes.

Detectable ems protein first appears in a stripe during stage 5 of development (Campos-Ortega and Hartenstein 1985), after the thirteenth nuclear division. Transcripts from ems are distributed in the same anterior stripe but are detectable one nuclear division cycle prior to the appearance of the protein [data not shown). During nuclear cycle $13,-2-2.5 \mathrm{hr}$ after fertilization, the syncytial nuclei are located in a peripheral monolayer. During the latter part of this stage, the nuclei elongate and are enclosed by cell membranes. Before cellularization is completed, the ems protein appears in a single circumferential stripe in the anterior region of the blastoderm (Fig. 7A). In the dorsal region, the stripe of ems-expressing cells, about five to six cells wide, appears from $75 \%$ to $69 \%$ egg length. The stripe gradually broadens from dorsal to ventral, encompassing about 10-12 cells in the ventral region. The expressing cells on the ventral aspect are located from $88 \%$ to $73 \%$ egg length.

During early gastrulation (stage 6; Campos-Ortega and Hartenstein 1985), the ems-expressing cells are located just anterior to the cephalic furrow. As the cephalic furrow deepens (during stages 7 and 8; Fig. 7B), a few rows of ems-expressing cells become located inside the furrow, as part of its anterior wall, ems protein disappears at this stage from the cells located on the dorsal anterior border of the cephalic furrow and appears to be expressed at lower levels than at the blastoderm stage. Some of the ems-expressing cells anterior to the cephalic furrow move into the anterior procephalon (Fig. 7B,C). This movement eventually results in a $90^{\circ}$ rotation of an oblong patch of ems-expressing cells, changing their dorsoventral orientation in the blastoderm band to an anteroposterior orientation in the lateral procephalon (cf. Fig. 7A-D). Such a $90^{\circ}$ rotation of the procephalic anlagen during gastrulation has been observed previously during fate-mapping studies of the anterior blastoderm (Technau and Campos-Ortega 1985). Like other homeo domain proteins, ems protein accumulates in the nucleus.

During stage 9 , cells that were part of the original head-specific expression pattern of ems protein are re- 
Structure and function of empty spiracles
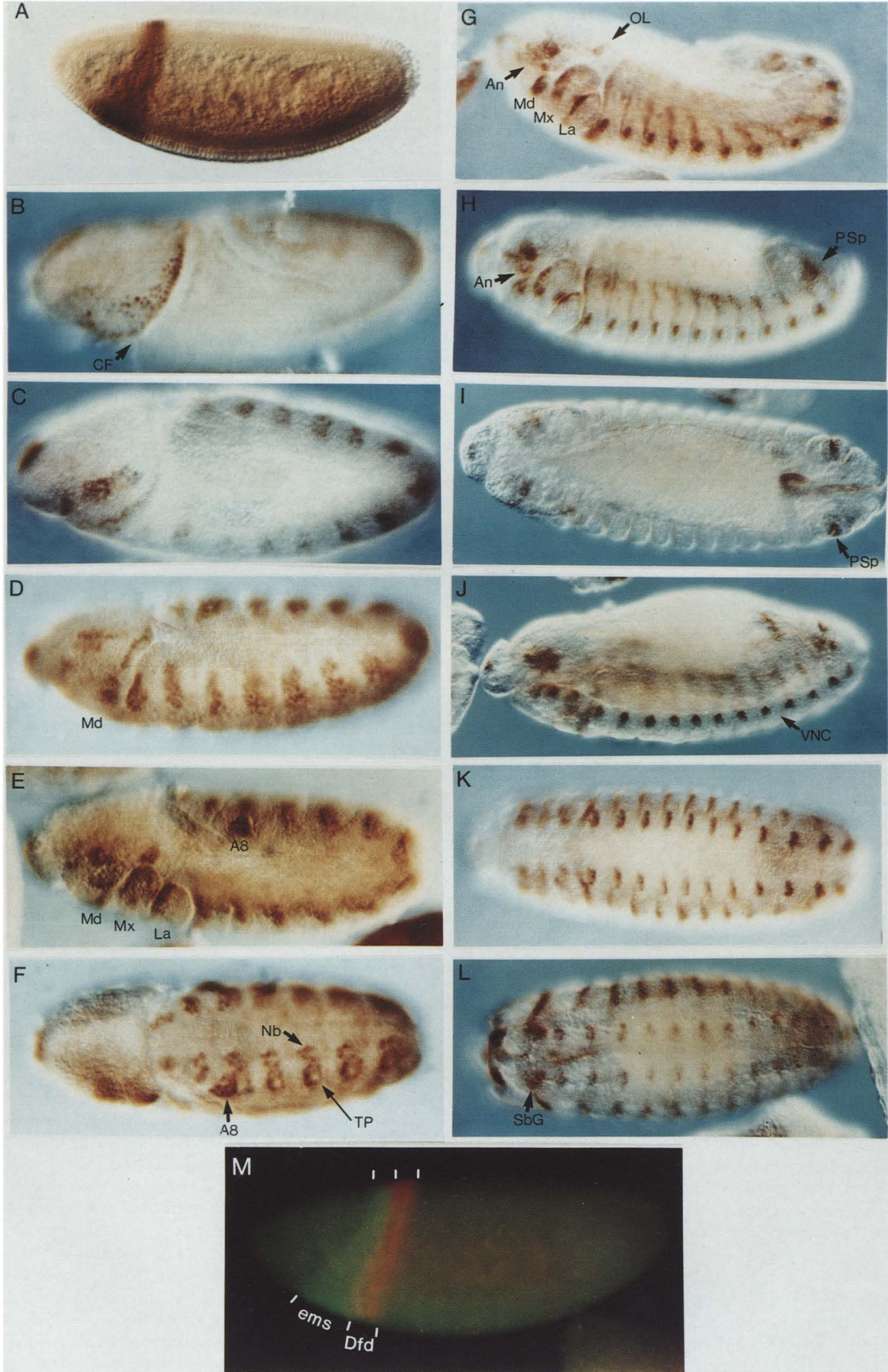

Figure 7. (See following page for legend.) 
solved into two separate regions of expression: The first is an oblong patch of cells in the lateral procephalon that extends to the lateral border of the stomodeum; the second patch is in the mandibular segment primordium, just within and anterior to the ventral cephalic furrow (Fig. 7C). By this stage, the metameric ems expression pattern is apparent, consisting of patches of ems-expressing cells in the lateral ectoderm of each head, thoracic, and abdominal segment primordium (Fig. 7C). Presumably, the continuous expression of ems protein from cellular blastoderm onward in some procephalic and mandibular cells is the result of the spatial overlap of the head-specific and metameric patterns. Although headspecific ems expression ends at germ-band extension, in the description below we detail ems expression in the head, especially in cells that originally comprised the blastoderm stripe, because this expression appears to be important for the developmental function of ems.

During late germ-band extension (stage 11), segmentation of the embryo becomes evident (Fig. 7E). The gnathal lobes (mandibular, maxillary, and labial) appear in the ventral region of the head. The large procephalic lobe occupies the upper, anterior part of the head. A prominent clypeolabral lobe appears anterior to the procephalic lobe. A slight bulge in the ventral procephalic lobe, above the mandibular segment, is the vestige of the antennal lobe visible in Drosophila embryos (Turner and Mahowald 1979; Jürgens et al. 1986). Most of the emsexpressing cells in the procephalon are found in the region just dorsal to the antennal lobe, although there is a single row of ems-expressing cells on the ventral rim of the antennal lobe (Fig. 7E). ems is also expressed in a small patch of cells located just dorsal to the maxillary lobe. According to the fate-mapping studies of Technau and Campos-Ortega (1985), this is the position of the optic lobe primordium.

During germ-band retraction (stage 12), the antennal lobe becomes more obvious as a bulge directly above the mandibular lobe (Fig. 7G). It appears that the ems-expressing cells have drawn together into a more discrete expression domain in this region. Some cells, especially in the dorsal region of the expression domain, stain more intensely than others. ems is also expressed, as part of the metameric expression pattern in the head, on the anterior borders of the mandibular, maxillary, and labial segments and at the tip of the clypeolabrum. After the germ band retracts (stage 13), ems protein is still abundantly expressed in the antennal lobe (Fig. $7 \mathrm{H})$, dorsal to the mandibular segment. Turner and Mahowald (1979), have shown previously that signs of the antennal sense organ first appear in this region after retraction of the germ band.

\section{ems Metameric expression pattern}

The metameric expression pattern from ems initiates at the beginning of germ-band extension (stage 8). By stage 9 , a small round patch of ems-expressing cells appears in the lateral ectoderm of each germ-band segment primordium (Fig. 7C). A patch of ems-expressing cells also appears in the dorsal procephalon; these cells eventually become located at the tip of the clypeolabrum.

During the rapid phase of germ-band elongation, ems antibody staining intensifies in the lateral patches of ectoderm. These patches are located in the primordia of the clypeolabrum, procephalic, mandibular, maxillary, labial, T1-T3, and Al-A10 segments. Shortly thereafter, most of the patches elongate dorsally (Fig. 7D). Because some of the cells in the lateral ectoderm undergo mitosis during stage 8 (Campos-Ortega and Hartenstein 1985), the elongation of the patches may be the result of the proliferation of a subset of the ems-expressing cells.

After the lateral ectoderm patches elongate, the emsexpressing cells separate into two different populations. This is consistent with the observation that the germ band of stage 9 embryos is organized into two morpho-

Figure 7. Expression of ems protein in embryos. $(A)$ Lateral view of a syncytial blastoderm stage embryo just at completion of cellularization. The ems protein is expressed in a single circumferential stripe in the anterior blastoderm. Although the ventral cytoplasm appears darker than the dorsal cytoplasm in this photo, the difference is artifactual and not the result of ems staining. In this and all subsequent panels, anterior is to the left. $|B|$ Lateral view of early gastrulating embryo. Many of the ems-expressing cells, located in front of the cephalic furrow, are moving into the anterior procephalon. $(C)$ Late stage 7 embryo. The late metameric ems expression pattern is appearing in patches in the lateral ectoderm of each segment primordia. $(D)$ Stage 8, or germ-band-extended embryo. Note elongation of the lateral ectoderm patches. (Md) Mandibular segment primordium. (E) Late germ-band-extended embryo. The gnathal lobes are prominent. The embryo is turned so that the mandibular lobe is in a ventral position. (Mx) Maxillary lobe; (La) labial lobe; (A8) eighth abdominal segment. Note the darkly stained patch on A8. (F) Dorsal view of an extended germ-band embryo. The tracheal pits (TP) have formed. A group of expressing cells are located medial to the tracheal pits and are likely to be segregating neuroblasts $(\mathrm{Nb}$ ). Note darkly staining patch in the eighth abdominal segment (A8). This region includes the filzkörper primordia. $(G)$ An embryo that is undergoing germ-band retraction. (Md, Mx, La) Gnathal lobes; (OL) optic lobe primordium. (H) An embryo that has completed germ-band retraction. (An) Antennal lobe; (PSp) posterior spiracles. Note faint staining along the lateral borders of each segment. Darkly staining cells appear in the region of the ventral nerve cord. (I) Dorsal view of an embryo that has completed germ-band retraction but not dorsal closure. The staining inside the posterior spiracles is indicated by an arrow. (/) Lateral view of a retracted germ-band embryo. The plane of focus is on the ventral nerve cord. Note darkly staining neural cells in every segment. $|K|$ Ventral view of an embryo that has undergone germ-band retraction. Note the extreme lateral positions of the darkly staining neural cells. There are three bilateral clusters of neural cells in the gnathal segments. $(L)$ Ventral view of a late embryo that is undergoing head involution. The staining neural cells have moved closer to the ventral midline. (SbG) Subesophageal ganglion. (M) A late cellular blastoderm stage embryo that has been stained with both $D f d$ (rhodamine)- and ems (fluorescein)-labeled antibodies. The ems expression domain is just anterior to the $D f d$ expression domain. At this stage, approximately one cell overlap of the expression domains occurs on their common border. 
logically different regions (Poulson 1950; Campos-Ortega and Hartenstein 1985|. The ventromedial and ventrolateral regions consist of large cells that are precursors of neuroblast and ventral epidermis. The lateral region consists of smaller cells that give rise to the tracheal pits and dorsal epidermis. On the basis of the subsequent fates of the ems-expressing cells in the elongated patches, the metameric ems expression includes cells from both the tracheal pit/dorsal epidermal cell population and the neuroblast population. The tracheal pits form in the dorsal region of the elongated patch in segments T2-A8 (Fig. 7E,F). Although the cells surrounding the tracheal pits express the ems protein, the cells in the center of the tracheal pits, which will divide and invaginate to form the tracheal tree, do not express ems. In the eighth abdominal segment (A8), a large patch of intensely staining cells is located just posterior to the tracheal pit (Fig. 7F). These cells extend throughout the dorsolateral region of $\mathrm{A} 8$ and appear to correspond to the primordia of the posterior spiracles and filzkörper (Turner and Mahowald 1979), which are defective in ems mutants.

At the same time the tracheal pits form, small groups of metamerically reiterated ems-expressing cells from the ventral ectoderm separate away from the elongated patches (Fig. 7F). Although we have not positively identified these cells, they may be the lateral longitudinal row neuroblasts, which segregate from the ectoderm during the extended germ-band stage (Hartenstein and Campos-Ortega 1984). As will be described in more detail below, these ems-expressing cells are eventually incorporated into the lateral margin of the ventral nerve cord.

During late germ-band elongation (stage 11), the gnathal buds appear in the ventral head region (Fig. 7E). The epidermal expression pattern of ems is slightly different in the mandibular, maxillary, labial, and first thoracic segments, which do not have tracheal pits. The ems-expressing cells are located on the lateral anterior border of each of these segments (Fig. 7E,G,H). Small clusters of ems-expressing lateral neuroblasts appear within the gnathal lobes and the first thoracic segment (Fig. 7G,H).

The segmental furrows form as the germ band retracts (stage 12). The ems-expressing cells previously surrounding the tracheal pits become organized into thin rows of cells oriented parallel to the segmental furrows (Fig. 7G). Once the segmental furrows are completed, at the end of germ-band retraction, the ems-expressing cells are located in rows along the anterior lateral segmental borders (Fig. $7 \mathrm{H}$ ). During germ-band retraction, the ems-expressing neural cells in all of the germ-band segments stain more intensely with the ems antibody. In contrast, the ems expression in the segmental furrows is rather weak. At this stage, the previously mentioned E5 homeo box gene establishes a transcript distribution pattern that overlaps with the expression of ems in the lateral anterior ectoderm of each segment (data not shown). Whether the two closely linked homeo box genes interact or cross-regulate is unknown at present.
Another pattern of ems expression appears at this stage in single lateral cells of the thoracic segments (Fig. 7G, $\mathrm{H})$.

An embryo that has completed germ-band retraction is shown in Figure $7 \mathrm{H}$. The tip of the clypeolabrum, as well as the lateral segmental borders of the gnathal, thoracic, and abdominal segments, stains weakly with the ems antibody. ems protein staining appears in the dorsal region of $\mathrm{A} 8$, inside the lumen of the newly formed posterior spiracles (Fig. $7 \mathrm{H}, \mathrm{I}$ ). These cells presumably give rise to the filzkörper. The lateral cells of the CNS stain intensely with the ems antibody (Fig. $7 \mathrm{H}, \mathrm{J}, \mathrm{K})$.

In the stage 15 embryo shown in Figure $7 \mathrm{~L}$, the ventral nerve cord has condensed toward the ventral midline (Campos-Ortega and Hartenstein 1985), drawing the ems-expressing neural cells toward the midline as well. The ems antibody staining in the CNS is limited to several cells per segment, located on the lateral margins of the ventral nerve cord. The ems-staining neural cells in the gnathal part of the CNS are condensed into the subesophageal ganglion (cf. Fig. $7 \mathrm{~K}$ and L). Faint staining can be still detected in the lateral ectoderm at the segmental borders.

\section{Expression of ems and Dfd in the cellular blastoderm}

The $D f d$ gene, which functions to specify head structures derived from the mandibular and maxillary segments (Merrill et al. 1987; Regulski et al. 1987; Kuziora and McGinnis 1988), is expressed in a single circumferential stripe in the anterior blastoderm (Jack et al. 1988). The posterior edge of the $D f d$ blastoderm stripe lies at the posterior boundary of parasegment 1 within the maxillary segment, whereas its anterior edge lies approximately at the anterior boundary of the mandibular segment. To determine the relative positions of the $D f d$ and $e m s$ blastoderm stripes, we stained wild-type embryos with both mouse anti-Dfd (T. Jack, unpubl.) and rabbit anti-ems antibodies. This allows separate detection of the antibodies with rhodamine-conjugated antimouse and fluorescein-conjugated anti-rabbit secondary antibodies. The embryo shown in Figure $7 \mathrm{M}$ is at stage 6 , very early gastrulation; a slight groove in the lateral region is the nascent cephalic furrow. The majority of ems-expressing cells (green/are located in a region of the blastoderm that is anterior and adjacent to the $D f d$ expression domain (orange). At this stage, approximately one row of cells expresses both ems and $D f d$ protein in the primordia of the anterior mandibular segment (Fig. $7 \mathrm{M})$.

\section{Expression of ems in bcd mutants}

One of the earliest events in the development of the Drosophila head is the determination of anterior polarity by the maternal gene $b c d$ (Frohnhöfer and Nüsslein-Volhard 1986). The bcd protein is expressed in a concentration gradient in the anterior region of the embryo (Driever and Nüsslein-Volhard 1988a) and influ- 
ences anterior positional identities in the embryo in a concentration-dependent manner (Driever and Nüsslein-Volhard 1988b). The bcd protein gradient is present for only a very short time during early embryogenesis. The early and persistent expression of ems in a subregion of the bcd morphogen gradient suggested that ems may sense a specific $b c d$ gradient value and thus be one of the genes that propagates and stably assigns a positional value originally specified by $b c d$.

Embryos derived from females with null mutations in bcd exhibit a loss of head and thoracic structures, together with an anterior duplication of the most posterior structures of the body pattern (Frohnhöfer and NüssleinVolhard 1986). We examined the expression of ems protein in embryos lacking maternal $b c d$. Blastoderm-stage bcd mutant embryos show no expression of the early head-specific ems blastoderm stripe (Fig. 8A). However, the metameric ems expression pattern is present in $b c d$ mutants (Fig. 8F). The staining intensity is reduced and the patches appear to be fused and irregular. The eighth abdominal segment is distinguished in normal embryos by a large, darkly stained patch of ems-expressing cells that are the filzkörper primordia (Fig. 7E,F). Such a large darkly staining patch appears on both ends of the germband-stage bcd embryos (Fig. 8F). This ectopic expression of the ems eighth abdominal patch is correlated with the appearance of filzkörper at both ends of the $b c d$ mutant embryo (Frohnhöfer and Nüsslein-Volhard 1986).

Deviations from the normal diploid dosage of $b c d$ in the mother result in changes in the levels of $b c d$ protein in the embryo (Driever and Nüsslein-Volhard 1988b). This causes a shift in the anterior fate map of the embryo along the AP axis. We examined ems expression in embryos collected from females with one, two, three, or four copies of $b c d$. The ems blastoderm band appears at $74 \%$ egg length in embryos from diploid females (Fig. 4C). The ems blastoderm band is shifted anteriorly to $82 \%$ with one dose of $b c d$ (Fig. 8B) and is shifted posteriorly to $70 \%$ with three doses (Fig. $8 \mathrm{D}$ ) and to $67 \%$ with four copies of $b c d$ (Fig. $8 \mathrm{E}$ ). Figure $8 \mathrm{H}$ contains a graphic comparison of the shift in the ems blastoderm stripe with the shift in the bcd immunostaining intensity that is normally present at $80 \%$ egg length, using the values from Driever and Nüsslein-Volhard (1988b; cf. our Fig. $8 \mathrm{H}$ with their Fig. 6). The shift in the ems blastoderm stripe follows the shift in bcd protein distribution reasonably well, except in the embryos with only one copy of $b c d$.

In embryos with mutations in both vasa and exuperantia (exu), the bcd protein is distributed at a moderate protein concentration throughout the embryo, with slightly higher levels near the anterior pole (Driever and Nüsslein-Volhard 1988b; Struhl et al. 1989). In vasa/exu double mutants, the ems blastoderm stripe is present at $\sim 84 \%$ egg length at the presumed anterior end of the blastoderm (Fig. 8G). This is the approximate position of the establishment of the ems blastoderm stripe in an embryo from a mother carrying only a single copy of bcd.

\section{Discussion}

The role of ems in embryonic patterning

Garcia-Bellido (1977) proposed that homeotic selector genes act through their persistent expression in specific segments to maintain a given developmental pathway for groups of embryonic cells. The current list of homeotic selectors that act to specify developmental fates on the AP axis of the embryo includes (from anterior to posterior in their domain of function), labial, Dfd, Scr, Antennapedia (Antp), Ultrabithorax (Ubx), abdominal $A(a b d-A)$, Abdominal $B(A b d-B)$, and caudal (for review, see Akam 1987). Except for caudal, all of these genes map in either the bithorax complex or the Antennapedia complex. The head-specific ems expression pattern and function satisfies Garcia-Bellido's definition and has many points of similarity with the other AP homeotic selectors. Beginning at cellular blastoderm, ems is expressed continuously in cells fated to give rise to antennal and mandibular segments (Fig. 9). In ems mutant embryos, many of the structures that normally develop from these segments of the head are missing.

The ems protein also shares several aspects of structural similarity with homeotic selector proteins. It contains a homeo domain that shares many of the conserved residues found in homeotic selectors, but is diverged in sequence overall $[<50 \%$ identity to Antp class homeo domains (McGinnis et al. 1984b; Scott and Weiner 1984; Regulski et al. 1985)]. Upstream of the homeo domain, the ems protein matches 4 out of 5 residues of a small conserved pentapeptide sequence, consisting of the core sequence Ile/Leu-Tyr-Pro-Trp-Met. In Drosophila, this motif is found in the homeotic selectors Dfd, Antp, Scr, and $U b x$. More diverged versions of the motif are also found in a similar position in labial ( 3 of 5 match) and caudal ( 2 of 5 match) (Mavilio et al. 1986; Schneuwly et al. 1986; Regulski et al. 1987; Weinzierl et al. 1987; Mlodzik et al. 1985; Diederich et al. 1989; LeMotte et al 1989). The homeo domain in the ems protein suggests that its developmental function is exerted through the transcriptional regulation of other genes (Desplan et al. 1985; Hoey and Levine 1988; Jaynes and O'Farrell 1988; Han et al. 1988); consistent with this, the ems protein is localized in the nucleus. Finally, the ems protein shares a region of acidic residues near the homeodomain with the $D f d$ protein and some other homeo domain proteins (Regulski et al. 1987); similar acidic regions function as transcriptional activation domains in the yeast transcription factors GCN4 and GAL4 (Hope and Struhl 1986; Ma and Ptashne 1987a,b; Hope et al. 1988). Based on the above comparisons, we propose that ems directs cells to mandibular and antennal fates in the same manner as homeotic selectors like Antp and $U b x$ direct segmental fates in more posterior segments.

Despite the similarities, ems differs from the other homeotic selector genes because it has no loss-of-function homeotic phenotype in the embryo, i.e., no structures characteristic of other segments develop in place of the missing structures in ems mutants. However, with the current understanding of homeotic phenotypes, this 


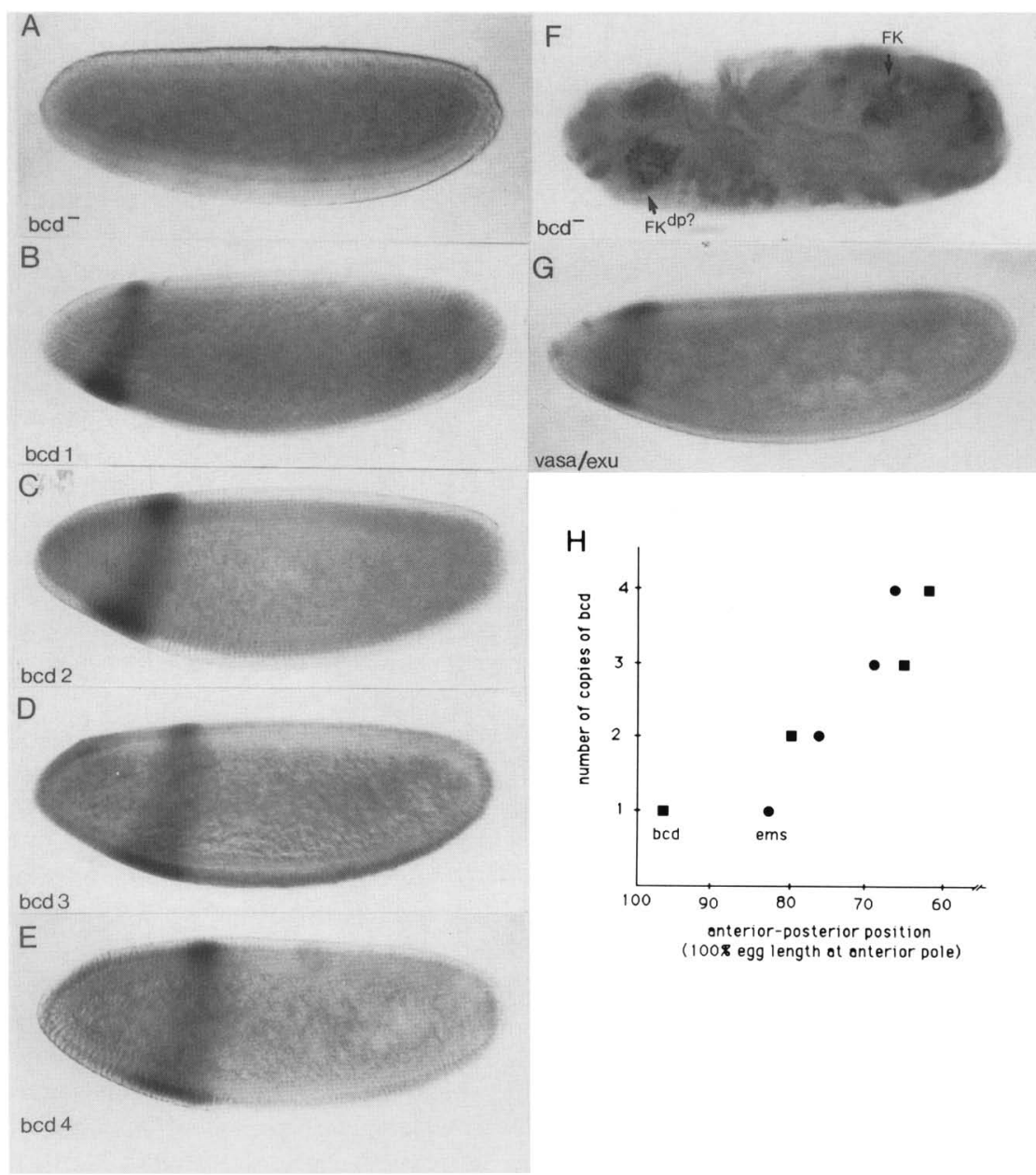

Figure 8. ems expression in $b c d$ variants. $(A-E$ and $G)$ Late syncytial or cellular blastoderm stage. One, two, three, and four copies of $b c d$ refer to the maternal genotype. (A) Cellular blastoderm-stage embryo from a $b c d$ null female. There is no detectable ems protein expression. (B) One copy of $b c d$. The ems stripe is established at $82 \pm 2 \%$ egg length. $(C)$ Two copies of $b c d$. The ems stripe is established at $74 \pm 2 \%$ egg length. $(D)$ Three copies of $b c d$. The ems stripe is established at $70 \pm 3 \%$ egg length. (E) Four copies of $b c d$. The ems stripe is established at $67 \pm 2 \%$ egg length. $(F)$ Extended germ-band-stage embryo from a bcd mutant female. Note the large darkly staining patch of cells [(FK) filzkörper primordia; (FKdp) duplicated filzkörper primordia] on both ends of the embryo. (G) Embryos derived from a vasa/exu mutant female. Stripe is at $84 \pm 2 \%$ egg length. $(H)$ A comparison of shifts in ems blastoderm stripe, normally at $74 \%$ in diploids, with $b c d$ immunostaining intensity found at $80 \%$ egg length in diploids. ( $\square$ ) The positions of equivalent immunostaining intensities in one, two, three, and four copies of bcd embryos. Distance measurements are percent embryonic length from the posterior pole to the center of the ems stripe in lateral positions; six to nine embryos were measured for each value reported above. ( $\bullet$ The positions of the ems stripe in one, two, three, and four copies of $b c d$. The $b c d 80 \%$ immunostaining intensities are taken from Fig. 6 in Driever and Nüsslein-Volhard (1986b). The exact values were communicated to us by W. Driever.

may simply be a result of its lack of cross-regulatory interactions with other homeotic selectors (Hafen et al. 1984). ems also differs from the other homeotic selectors in having a second expression pattern and function that seem unrelated to its early role in the head region. The metameric ems expression pattern resembles the expression patterns of some of the segment polarity genes, as it is expressed in a subset of cells within each segment primordium (DiNardo et al. 1985; Baker 1987; Baumgartner et al. 1987). However, unlike the known segment polarity genes, which initiate expression at the cellular blastoderm stage, the expression of the ems metameric pattern initiates after gastrulation. In addition, the segment polarity genes have a patterning function in every segment (Nüsslein-Volhard and Wieschaus 1980), whereas the metameric ems expression pattern appears to be required only for the morphogenesis of structures in the eighth abdominal segment.

\section{Correlation of ems expression with mutant defects}

ems expression patterns in the embryonic head are correlated with the head fate maps of Jürgens et al. (1986) in Figure 9. The cells that express ems at the cellular blastoderm are fated to give rise to a variety of head structures, including the antennal sense organs, the dorsal arms, the vertical plates, and the lateralgräten. All of these structures are missing or disrupted in ems mutant 

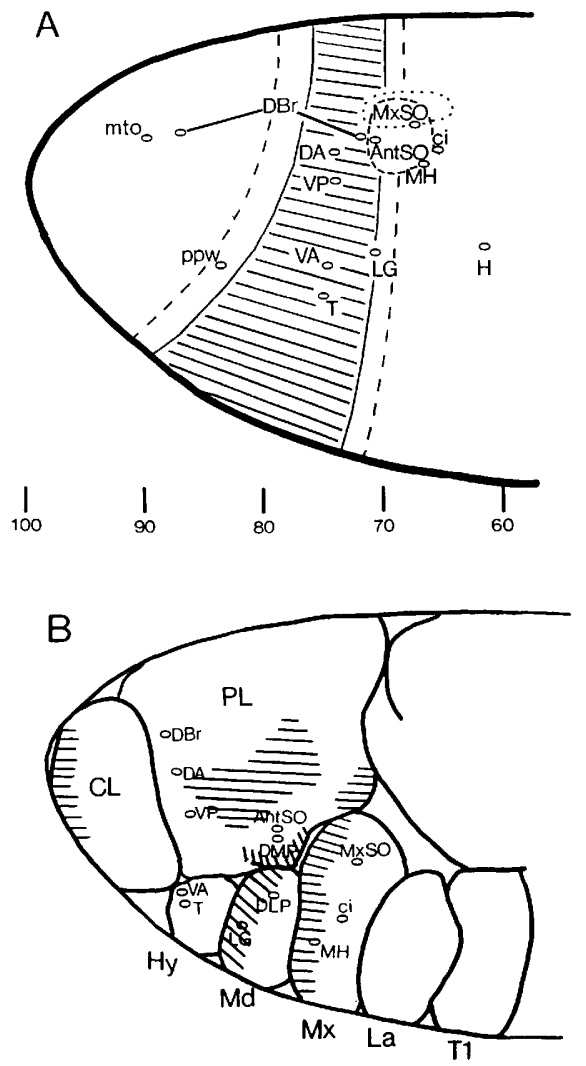

Figure 9.The ems expression pattern in the head and the ems phenotype. The ems protein staining pattern (hatched lines) is superimposed on diagrams of the cellular blastoderm $\langle A|$, and extended germ-band fate maps $(B)$ of Jürgens et al. (1986). The diagrams were redrawn from Jürgens et al. (1986), with the elimination of the primordia for several small sensory structures that we were unable to score in ems mutants. The primordia for structures eliminated in ems mutants are the antennal sense organs (AntSO), lateralgräten (LG), dorsal arms (DA), vertical plates (VP), dorsolateral papillae (DLP), and dorsomedial papillae (DMP). The primordia for structures that are normal in ems mutants are median tooth (mto), posterior wall of pharynx (ppw), dorsal bridge (DBr), ventral arms (VA), T-ribs (T), maxillary sense organs (MxSO), cirri (ci), mouth hooks $(\mathrm{MH})$, and $\mathrm{H}$-piece $(\mathrm{H})$. The lobes of the embryonic head are clypeolabral lobe (CL), procephalic lobe (PL), hypopharyngeal lobe $(\mathrm{Hy})$, mandibular lobe $(\mathrm{Md})$, maxillary lobe $(\mathrm{Mx})$, labial lobe (La), and first thoracic segment (T1).

embryos (Fig. 9A). At the extended germ-band stage, when the head lobes appear, the primordia of several of these structures are located in the lateral procephalon. The antennal sense organs and the DMP have been approximately mapped to the antennal lobe of the lateral procephalon. We find that ems is expressed within a part of the antennal lobe. Similarly, the cells fated to secrete the dorsal arms and the vertical plates have been mapped to the anterolateral procephalon, where ems protein is expressed. The lateralgräten and the DLP have been mapped to the mandibular segment, where ems protein is persistently expressed on the anterior border. The cellular blastoderm primordia of the ventral arms and the T-ribs of the pharynx also express ems protein.
Both of these structures develop normally in ems mutants; however, the primordia for the ventral arms and T-ribs are incorporated into the hypopharyngeal lobe at the extended germ-band stage and do not persistently express ems protein (Fig. 9B). The head structures that are missing in the ems mutant are those whose primordia express ems protein persistently from cellular blastoderm stage until late stages of embryogenesis.

The metameric expression pattern of ems in ectoderm along the anterior-lateral segment borders is not associated with any obvious segmental cuticular defects. However, we have not analyzed the fate of every embryonic structure that develops from these cells, some of which are internal, and subtle defects may have escaped our notice. In the eighth abdominal segment, abundant and extensive ems expression is observed in the anterior lateral ectoderm and is required for the morphogenesis of the posterior tracheal tubes and the filzkörper. The metameric ems expression pattern in the thorax and first seven abdominal segments appears to be less abundant, as measured by antibody staining intensity, than the staining intensity in the head or in the eighth abdominal segment. This weak expression may account, in part, for the lack of obvious phenotypic effect.

Primitive members of the annelid-arthropod lineage, such as the millipedes, have spiracles in every trunk segment (Snodgrass 1935). It is tempting to speculate that $\mathrm{ems}$ might have a segmentally reiterated function in these simpler arthropods-as it apparently does in the eighth abdominal segment of Drosophila-to specify the connection of the tracheal tree to the segmentally reiterated spiracles. The weak expression of ems in the lateral ectoderm of thoracic and anterior abdominal segments might be an evolutionary remnant of this speculative ancestral function.

\section{Interaction of ems with the anterior patterning gene bcd}

The lack of expression of the ems blastoderm stripe in $b c d$ mutants indicates that $b c d$ is required to initiate the ems blastoderm stripe. Recent experiments have shown that $b c d$ protein is a positive transcriptional regulator of hunchback transcription in the anterior half of the embryo and likely effects this regulation by directly binding to hunchback upstream regulatory sequences (Tautz 1988; Driever and Nüsslein-Volhard 1989; Struhl et al. 1989). Whether the $b c d$ regulatory effect on $e m s$ is direct or indirect is unknown, but ems expression does exhibit a concentration-dependent response to $b c d$ levels. The early initiation of the ems blastoderm stripe of expression is consistent with a direct regulatory role for $b c d$, and the anterior positioning of the ems stripe in wildtype and vasa/exu mutant embryos suggests that ems regulatory sequences might respond only to relatively high $b c d$ levels.

\section{Materials and methods}

\section{Library screens}

The nick-translated, eve homeo box probe was a gel-purified, 
440-bp fragment isolated from pUCeve9. The 440-bp insert in this clone consists of two tandem copies of a 220-bp HinfI-AccI fragment containing the eve homeo box. A Drosophila $\lambda \mathrm{EMBL} 4$ genomic library consisting of Sau3A partially digested Drosophila DNA ligated into BamHI-digested $\lambda \mathrm{EMBL} 4$ arms was a generous gift from Anette Preiss. The library was screened with the 440-bp eve probe, using reduced stringency hybridization conditions as described in McGinnis et al. (1984a). For classifying the clones, high-stringency hybridization conditions were performed as described in McGinnis et al. (1984). The ems cDNAs were isolated from a Drosophila $\lambda$ gt 10 cDNA library derived from 3- to 12-hr embryonic poly(A) RNA, a generous gift from L. Kauvar and T. Kornberg (Poole et al. 1985).

\section{In situ hybridization to polytene chromosomes}

Labeling of the DNA probes with biotin was done by using the method of Feinberg and Vogelstein (1983) with the modification that biotin-labeled dUTP at a concentration of $0.3 \mathrm{~mm}$ was used in place of dTTP. Preparation and hybridization of the chromosomes was performed as described in Langer-Safer et al. (1982). Enzymatic detection of the biotinylated probes was done using a strepavidin/horseradish peroxidase conjugate (ENZO Biochemicals), followed by staining with diaminobenzidine.

\section{RNA extraction and Northern analysis}

RNA extraction from embryos, electrophoresis, blotting, hybridization, and washes was performed as described in Chadwick and McGinnis (1987). A 4.1-kb EcoRI-HindIII fragment containing the E4/ems transcription unit (Fig. 2) was used to probe the developmental Northern blot.

\section{Sequencing}

The ems cDNA was subcloned into pBluescript (Stratagene), and exonuclease III was used to create nested deletion clones for each strand. The coding strand was sequenced directly from the pBluescript template using the procedure described in Toneguzzo et al. (1988), with the modification that the CsCl-purified templates were denatured at room temperature. The deletion clones of the noncoding strand were subcloned into M13 for single-stranded sequencing. Sequencing was performed by the dideoxynucleotide sequencing procedure of Sanger et al. (1977), using a protocol incorporating a modified form of T7 polymerase (Sequenase, U.S. Biochemical).

\section{Isolation and sequencing of the ems genomic DNA}

A genomic library in $\lambda$ gt10 was made from EcoRI-digested, $e m s^{9 H} / T M 3$ DNA, and six 5.4-kb EcoRI fragments (see Fig. 2) containing the E4/ems transcription unit were isolated. The clones derived from the $e m s^{9 H}$ mutant chromosome were distinguished from the TM3-derived clones by the presence of a restriction fragment length polymorphism caused by a missing PstI site. A backcross of the $e m s^{9 H}$ stock to the homozygous rucuca parental strain established that the PstI polymorphism derives from the $e m s^{9 H}$ chromosome. The $e m s^{9 H} 5.4-\mathrm{kb}$ fragment was subcloned into pBluescript and sequenced, using specific primers derived from the cDNA sequence.

To isolate the E4 transcription unit from the mutant $e m s^{9 Q}$, 200 mutant embryos were hand-picked from a 20-hr-old embryo collection. Genomic DNA was prepared as described in Jowett (1986). The DNA was digested with EcoRI and ligated into $\lambda$ gt10 arms. The 5.4-kb EcoRI fragment that contains the
E4 transcription unit was isolated from the library and subcloned into pBlueScript for sequence analysis.

\section{Fly stocks}

The wild-type strain was Oregon $\mathrm{R}$. The complete genotypes of the ems alleles are as follows: $e m s^{7 D}=e m s^{7 D 99} \mathrm{ru} h$ th st $\mathrm{cu}$ sr $e^{s} c a / T M 3, S b$ Ser; $e m s^{9 Q}=e m s^{9064} r u$ h th st cu sr $e^{s}$ $c a / T M 3, S b$ Ser; ems $s^{9 H}=e m s^{9 H 83}$ ru h th st cu sr $e^{s} c a / T M 3$, $\mathrm{Sb}$ Ser (Jürgens et al. 1984). The parental stock for ems was:

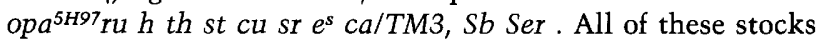
were independently generated from a mutagenized stock of the genotype ru h th st cu sr $e^{s} c a$ (Jürgens et al. 1984). The ems stocks were generously sent to us by Eric Wieschaus. The opa ${ }^{5 H^{97}}$ stock was obtained from the Mid-America Drosophila Stock Center (Bowling Green, Ohio). The bcd mutant strains are described in Driever and Nüsslein-Volhard (1988b), and the vasa/exu double mutant is described in Schüpbach and Wieschaus (1986).

The deficiency stocks $D f(3 R)$ red $^{p 52}, \quad D f(3 R)$ red $^{1}$, and $D f(3 R) f s 293^{\gamma 5}$ were generously provided to us by Richard Kelley. The $D f(3 R)$ red $^{552}$ proximal breakpoint is approximately $88 \mathrm{~A} 4$. The $D f(3 R)$ red $^{1}$ proximal breakpoint is imprecisely mapped within the $88 \mathrm{~A}$ region, possibly near $88 \mathrm{~A} 3$. The $D f(3 R) f s 293^{\gamma 5}$ distal breakpoint is approximately $88 \mathrm{~A} 6$. (These results were communicated to us by Richard Kelley, who has done a chromosomal walk in this region.) The deficiency stock $D f(3 R) \mathrm{red}^{3 I} / \mathrm{MKRS}$ was obtained from the Mid-America Drosophila Stock Center. The proximal breakpoint of this chromosome is 87F12-87F14 (Hall and Kankel 1976). The deficiency stock $D f(3 R) r y^{85}$ was a generous gift of Allen Shearn. The distal breakpoint of this chromosome is 87F15-88Al (Hall and Kankel 1976).

\section{Expression and purification of the ems fusion protein and} production of antibodies

To produce ems protein in Escherichia coli, we used the T7 expression system of Studier and Moffatt (1986). A PstI-EcoRI fragment, extending from nucleotide 329 to 2207 of the ems cDNA pE4cDNA12, was cloned into the PstI-EcoRI site of pBluescript (Stratagene). The fragment was reisolated from the pBluescript plasmid by digestion with $B a m H I$ and EcoRV. $B a m H I$ linkers were added to the blunt EcoRV ends, and the fragment was subcloned into the unique BamHI site of the T7 expression vector $\mathrm{pAR} 3038$. The resulting plasmid, designated $\mathrm{pEP}$, contains the T7 promoter and the first 11 amino acids of the $\mathrm{T} 7$ gene 10, four amino acids from the pBluescript polylinker (the region between the PstI and BamHI sites) and amino acids $11-494$, and $432 \mathrm{bp}$ of untranslated DNA from the ems cDNA. The pEP expression plasmid was transformed into the E. coli strain BL21-DE3, which contains a T7 RNA polymerase gene under the control of the lac promoter (Studier and Moffatt 1986).

For induction experiments, L-Amp plates were inoculated with transformed cells from a frozen stock. The colonies were used to inoculate 0.5 liter of L-Amp supplemented with $0.4 \%$ glucose to a density of $A_{600}=0.3$. After one doubling, isopropylthiogalactosidase (IPTG) (Sigma) was added to a concentration of $0.4 \mathrm{mM}$ to induce the expression of the T7 RNA polymerase, which then synthesizes RNA from the pEP expression vector. After $1 \mathrm{hr}$ of further growth, the cells were harvested and resuspended in $35 \mathrm{ml}$ of lysis buffer containing $50 \mathrm{mM}$ sodium phosphate buffer ( $\mathrm{pH}$ 7.5), $10 \mathrm{mM}$ EDTA, $1 \mathrm{mM}$ PMSF, 10 mM $\beta$-mercaptoethanol, $20 \mathrm{mg}$ of lysozyme, and $0.1 \%$ Triton $\mathrm{X}-100$ detergent (IBI). After $30 \mathrm{~min}$ of incubation at $4^{\circ} \mathrm{C}$ with 
the lysozyme, the cells were lysed by passage through a French press. The quantity of $3.5 \mathrm{ml}$ each of $5 \mathrm{M} \mathrm{NaCl}$ and $30 \%$ streptomycin sulfate was stirred into the lysate, which was then cleared by spinning at $17,000 \mathrm{~g}$ for $10 \mathrm{~min}$. The volume of the lysate was doubled by the addition of lysis buffer. Ammonium sulfate from a saturated solution $(\mathrm{pH} 7.0)$ was added to a final concentration of $33 \%$. The $33 \%$ precipitate was pelleted by spinning at $17,000 \mathrm{~g}$ for $10 \mathrm{~min}$. The pellet was resuspended and dialyzed against $20 \mathrm{~mm}$ sodium phosphate $(\mathrm{pH} 7.0), 10 \mathrm{~mm}$ EDTA, and $1 \mathrm{mM}$ PMSF. The protein was fractionated on a preparative SDS-PAGE gel, and the band containing the fusion protein was excised from the gel. The gel slice was ground to a fine suspension in phosphate-buffered saline using a Dounce homogenizer and then mixed with an equal volume of Freund's adjuvant. A New Zealand white rabbit was injected at multiple subcutaneous sites with $\sim 100 \mu \mathrm{g}$ of protein. Two months later, the rabbit was boosted with $\sim 50 \mu \mathrm{g}$ of protein, and 10 days later, ems-specific antibodies were detected in the serum. Serum collected after a second $50-\mu \mathrm{g}$ boost was used for embryo staining.

\section{Collection and staining of whole-mount embryos}

The ems antiserum was diluted $1: 50$ and immunoabsorbed with fixed, devitellinized 0- to 2-hr or 0- to 6-hr Drosophila embryos. Whole-mount embryo collection and fixation was performed as described in Jack et al. (1988). ems antiserum was used at a final dilution of $1: 1000$ for embryo staining. The secondary antibody was a biotinylated goat anti-rabbit IgG (Jackson ImmunoResearch), diluted $1: 500$ to a concentration of $2 \mathrm{mg} / \mathrm{ml}$. Detection of the secondary antibody was done using an avidin/biotin/horseradish peroxidase complex (Vectastain from Vector Laboratories), with diaminobenzidine (Sigma) as a substrate. The mouse anti- $D f d$ antiserum was a gift from Tom Jack.

\section{Acknowledgments}

We are particularly grateful to Eric Wieschaus for providing all five mutant alleles of ems, as well as to Richard Kelley for providing helpful advice, for sharing unpublished results on his chromosome walk through the $88 \mathrm{~A}$ region, and for providing Drosophila deficiency chromosome stocks. We also thank Allen Shearn and the Mid-America Drosophila Stock Center for providing mutant fly strains, and Nadine McGinnis and Bradley Jones for their help in determining cytological locations of the new homeo box clones. We thank Tom Jack for advice on antibody-staining procedures and for the mouse anti- $D f d$ antibody. We are grateful to Wolfgang Driever for the $b c d$ mutant strains and for valuable discussions. William Studier provided very helpful advice about the T7 expression system. We thank Trudi Schüpbach for the vasa/exu double mutant strain. Larry Kauvar, Tom Kornberg, and Anette Preiss generously provided cDNA and genomic libraries. We also thank Tom Jack and Scott Dessain for helpful criticism of the manuscript. D.D. was the recipient of a National Science Foundation predoctoral fellowship and National Institutes of Health predoctoral training grant HD07149. This research was supported by grants from the Searle Scholar Program and the American Cancer Society to W.M.

\section{References}

Akam M. 1987. The molecular basis for metameric pattern in the Drosophila embryo. Development 101: 1-22.
Baker, N. 1987. Molecular cloning of sequences from wingless, a segment polarity gene in Drosophila: The spatial distribution of a transcript in embryos. EMBO I. 6: 1765-1774.

Barad, M., T. Jack, R. Chadwick, and W. McGinnis. 1988. A novel, tissue-specific, Drosophila homeobox gene. EMBO $J$. 7: $2151-2161$.

Baumgartner, S., D. Bopp, M. Burri, and M. Noll. 1987. Structure of two genes at the gooseberry locus related to the paired gene and their spatial expression during Drosophila embryogenesis. Genes Dev. 1: 1247-1267.

Berleth, T., M. Burri, G. Thoma, D. Bopp, S. Richstein, G. Frigerio, M. Noll, and C. Nüsslein-Volhard. 1988. The role of localization of bicoid RNA in organizing the anterior pattern of the Drosophila embryo. EMBO I. 7: 1749-1756.

Campos-Ortega, J.A. and V. Hartenstein. 1985. The embryonic development of Drosophila melanogaster. Springer-Verlag, Berlin.

Capdevila M.P. and A. Garcia-Bellido. 1981. Genes involved in the activation of the Bithorax Complex in Drosophila melanogaster. Wilhelm Roux's Arch. Dev. Biol. 190: 339-350.

Cavener, D. 1987. Comparison of the consensus sequence flanking translational start sites in Drosophila and vertebrates. Nucleic Acids Res. 15: 1353-1361.

Chadwick, R. and W. McGinnis. 1987. Temporal and spatial distribution of transcripts from the Deformed gene of Drosophila. EMBO I. 6: 779-789.

Diederich, R., V. Merrill, M. Pultz, and T. Kaufman. 1989. Isolation, structure, and expression of labial, a homeotic gene of the Antennapedia Complex involved in Drosophila head development. Genes Dev. 3: 399-414.

Desplan, C., J. Theis, and P.H. O'Farrell. 1985. The Drosophila developmental gene, engrailed, encodes a sequence-specific DNA binding activity. Nature 318: 630-635.

- 1988. The sequence specificity of homeodomain-DNA interaction. Cell 54: 1081-1090.

DiNardo, S., J.M. Kuner, J. Theis, and P.H. O'Farrell. 1985. Development of embryonic pattern in $D$. melanogaster as revealed by accumulation of the nuclear engrailed protein. Cell 43: 59-69.

Driever, W. and C. Nüsslein-Volhard. 1988a. A gradient of bicoid protein in Drosophila embryos. Cell 54: 83-93.

- 1988b. The bicoid protein determines position in the Drosophila embryo in a concentration-dependent manner. Cell 54: 95-104.

. 1989. The bicoid protein is a positive regulator of hunchback transcription in the early Drosophila embryo. Nature 337: 138-143.

Feinberg, A.P. and B. Vogelstein. 1983. A technique for labeling DNA restriction endonuclease fragments to high specific activity. Anal. Biochem. 132: 6-13.

Frasch, M., T. Hoey, C. Rushlow, H. Doyle, and M. Levine. 1987. Characterization and localization of the even-skipped protein of Drosophila. EMBO J. 6: 749-759.

Frigerio, G., M. Burri, D. Bopp, S. Baumgartner, and M. Noll. 1986. Structure of the segmentation gene paired and the Drosophila PRD gene set as part of a gene network. Cell 47: 735-746.

Frohnhöfer, H.G. and C. Nüsslein-Volhard. 1986. Organization of anterior pattern in the Drosophila embryo by the maternal gene bicoid. Nature 324: 120-125.

Gans, M., F. Forquignon, and M. Masson. 1980. The role of the region 7D1-7D5 of the X-chromosome in the production of homeotic transformations in Drosophila melanogaster. Genetics 96: 887-902.

Garcia-Bellido, A. 1977. Homeotic and atavic mutations in insects. Am. Zool. 17: 613-628. 
Gibson, G. and W.J. Gehring. 1988. Head and thoracic transformation caused by ectopic expression of Antennapedia during Drosophila development. Development 102: 657675.

Hafen, E., M. Levine, and W.J. Gehring. 1984. Regulation of Antennapedia transcript distribution by the bithorax complex in Drosophila. Nature 307: 287-289.

Hall, J. and D. Kankel. 1976. Genetics of acetylcholinesterasein Drosophila melanogaster. Genetics 83: 517-535.

Han, K., M.S. Levine, and J.L. Manley. 1989. Synergistic activation and repression of transcription by Drosophila homeobox proteins. Cell 56: 573-583.

Hartenstein, V. and J.A. Campos-Ortega. 1984. Early neurogenesis in wild-type Drosophila melanogaster. Wilhelm Roux's Arch. Dev. Biol. 193: 308-325.

Hoey, T. and M. Levine. 1988. Divergent homeo box proteins recognize similar DNA sequences in Drosophila. Nature 332: $858-861$.

Hope, I.A. and K. Struhl. 1986. Functional dissection of a eukaryotic transcriptional activator protein, GCN4 of yeast. Cell 46: 885-894.

Hope, I.A., S. Mahadevan, and K. Struhl. 1988. Structural and functional characterization of the short acidic transcriptional activation region of yeast GCN4 protein. Nature 333: 635-640.

Jack, T., M. Regulski, and W. McGinnis. 1988. Pair-rule segmentation genes regulate the expression of the homeotic selector gene, Deformed. Genes Dev. 2: 635-651.

Jaynes, J.B. and P.H. O'Farrell. 1988. Activation and repression of transcription by homeodomain-containing proteins that bind a common site. Nature 336: 744-749.

Jowett, T. 1986. Preparation of nucleic acids. In Drosophila: $A$ practical approach (ed. D.B Roberts), pp. 275-286. IRL Press, Oxford.

Jürgens, G., R. Lehman, M. Schardin, and C. Nüsslein-Volhard. 1986. Segmental organization of the head in the embryo of Drosophila melanogaster. Wilhelm Roux's Arch. Dev. Biol. 195: 359-377.

Jürgens, G., E. Wieschaus, C. Nüsslein-Volhard, and H. Kluding. 1984. Mutations affecting the pattern of the larval cuticle in Drosophila melanogaster. II. Zygotic loci on the third chromosome. Wilhelm Roux's Arch. Dev. Biol. 193: $283-295$.

Kaufman, T. 1983. Genetic regulation of segmentation in Drosophila melanogaster. In Time, space, and pattern in embryonic development. (ed. W.R. Jeffrey and R.A. Raff), pp. 365-383. Alan R. Liss, New York.

Krasnow, M.A., E.E. Saffman, K. Kornfeld, and D.S. Hogness. 1989. Transcriptional activation and repression by Ultrabithorax proteins in cultured Drosophila cells. Cell 57: $1031-1043$.

Kuroiwa, A., U. Kloter, P. Baumgartner, and W.J. Gehring. 1985. Cloning of the homeotic Sex combs reduced in Drosophila and in situ localization of its transcripts. EMBO J. 4: 37573764.

Kuziora, M. and W. McGinnis. 1988. Autoregulation of a Drosophila homeotic selector gene. Cell 55: 477-485.

Langer-Safer, P.R., M. Levine, and D.C. Ward. 1982. Immunological method for mapping genes on Drosophila polytene chromosomes. Proc. Nat1. Acad. Sci. 79; 4381-4385.

LeMotte, P., A. Kuriowa, L. Fessler, and W. Gehring. 1989. The homeotic gene Sex Combs Reduced of Drosophila: Gene structure and embryonic expression. EMBO J. 8: 219-227.

Levine, M., K. Harding, C. Wedeen, H. Doyle, T. Hoey, and H. Radomska. 1985. Expression of the homeo box gene family in Drosophila. Cold Spring Harbor Quant. Symp. Biol. 50: $209-222$.
Lewis, E.B. 1978. A gene complex controlling segmentation in Drosophila. Nature 276: 565-570.

Ma, J. and M. Ptashne. 1987a. Deletion analysis of GAL4 defines two transcriptional activating segments. Cell 48: 847853.

1987b. A new class of yeast transcriptional activators. Cell 51: 113-119.

MacDonald, P.M. and G. Struhl. 1986. Molecular gradient in early Drosophila embryos and its role in specifying the body pattern. Nature 324: 537-545.

MacDonald, P.M., P. Ingham, and G. Struhl. 1986. Isolation, structure and expression of even-skipped: A second pair-rule gene of Drosophila containing a homeo box. Cell 47: 721734.

Mavilio, F., A. Simeone, A. Giampaolo, A. Faiella, V. Zappavigna, D. Acampora, G. Poiana, G. Russo, C. Peschle, and E. Boncinelli. 1986. Differential and stage-related expression in embryonic tissues of a new human homeo box gene. Nature 324: 664-667.

McGinnis, W., R.L. Garber, J. Wirz, A. Kuroiwa, and W.J. Gehring. 1984a. A homologous protein-coding sequence in Drosophila homeotic genes and its conservation in other metazoans. Cell 37: 403-408

McGinnis, W., M. Levine, E. Hafen, A. Kuroiwa, and W.J. Gehring. 1984b. A conserved DNA sequence found in homeotic genes of the Drosophila Antennapedia and Bithorax complexes. Nature 308: 428-433.

Merrill, V.K.L., F.R. Turner, and T.C. Kaufman. 1987. A genetic and developmental analysis of mutations in the Deformed locus of Drosophila melanogaster. Dev. Biol. 122: 370-395.

Mlodzik, M., A. Fjose, and W.J. Gehring. 1985. Isolation of caudal, a Drosophila homeo box-containing gene with maternal expression whose transcripts form a concentration gradient at the pre-blastoderm stage. EMBO J. 4: 29612969.

Nüsslein-Volhard, C. and E. Wieschaus. 1980. Mutations affecting segment number and polarity in Drosophila. Nature 287: $795-801$.

Nüsslein-Volhard, C., H. Frohnhöfer, and R. Lehmann. 1987. Determination of anteroposterior polarity in Drosophila. Science 238: 1675-1681.

Poole, S.J., L.M. Kauvar, B. Drees, and T. Kornberg. 1985. The engrailed locus of Drosophila: Structural analysis of an embryonic transcript. Cell 40: 37-47.

Poulson, D.F. 1950. Histogenesis, organogenesis and differentiation in the embryo of Drosophila melanogaster Meigen. In Biology of Drosophila (ed. M. Demerec), pp. 168-270. Wiley and Sons, New York.

Regulski, M., N. McGinnis, R. Chadwick, and W. McGinnis. 1987. Developmental and molecular analysis of Deformed: A homeotic gene controlling Drosophila head development. EMBO J. 6: 767-777.

Regulski, M., K. Harding, R. Kostriken, F. Karch, M. Levine, and W. McGinnis. 1985. Homeo box genes of the Antenna pedia and Bithorax complexes of Drosophila. Cell 43: 7180.

Rushlow, C., H. Doyle, T. Hoey, and M. Levine. 1987. Molecular characterization of the zerknüllt region of the Antennapedia gene complex in Drosophila. Genes Dev. 1: 12681279.

Saint, R., B. Kalionis, T.J. Lockett, and A. Elizur. 1988. Pattern formation in the developing eye of Drosophila melanogaster is regulated by the homeobox gene, rough. Nature 334: 151-154.

Sanger, F., S. Nicklen, and A.R. Coulson. 1977. DNA sequencing with chain terminating inhibitors. Proc. Natl. 
Dalton et al.

Acad. Sci. 74: 5463-5467.

Schneuwly, S., A. Kuroiwa, P. Baumgartner, and W. Gehring. 1986. Structural organization and sequence of the homeotic gene Antennapedia of Drosophila melanogaster. EMBO I. 5: $733-739$.

Schüpbach, T. and E. Wieschaus. 1986. Maternal effect mutations altering the anterior-posterior pattern of the Drosophila embryo. Wilhelm Roux's Arch. Dev. Biol. 195: 302317.

Scott, M.P. and A. Weiner. 1984. Structural relationships among genes that control development: Sequence homology between the Antennapedia, Ultrabithorax, and fushi tarazu loci of Drosophila. Proc. Natl. Acad. Sci. 81: 4115-4119.

Scott, M.P., J.W. Tamkun, and G.W. Hartzell. 1989. The structure and function of the homeodomain. Biochim. Biophys. Acta 989: 25-48.

Snodgrass, R.E. 1935. Principles of insect morphology. McGraw-Hill, London and New York.

Struhl, G. 1983. Role of the $e^{+} c^{+}$gene product in ensuring the selective expression of segment-specific homeotic genes in Drosophila. I. Embryol. Exp. Morphol. 76: 297-331.

Struhl, G., K. Struhl, and P.M. Macdonald. 1989. The gradient morphogen bicoid is a concentration-dependent transcriptional activator. Cell 57: 1259-1273.

Studier, F.W. and B.A. Moffatt. 1986. Use of bacteriophage T7 RNA polymerase to direct selective high-level expression of cloned genes. J. Mol. Biol. 189: 113-130.

Tautz, D. 1988. Regulation of the Drosophila segmentation gene hunchback by two maternal morphogenetic centres. Nature 332: 281-284.

Technau, G. and J. Campos-Ortega. 1985. Fate mapping in wild type Drosophila melanogaster. II. Injections of horseradish peroxidase in cells of the early gastrula stage. Roux Arch. Dev. Biol. 194: 196-212.

Tomlinson, A., B.E. Kimmel, and G.E. Rubin. 1988. rough, a Drosophila homeobox gene required in photoreceptors R2 and $\mathrm{R} 5$ for inductive interactions in the developing eye. Cell 55: $771-784$.

Toneguzzo, F., S. Glynn, E. Levi, S. Mjolsness, and A. Hayday. 1988. Use of a chemically modified T7 DNA polymerase for manual and automated sequencing of supercoiled DNA. Biotechniques 6: 460-469.

Turner, F.R. and A.P. Mahowald. 1979. Scanning electron microscopy of Drosophila melanogaster embryogenesis. III. Formation of the head and caudal segments. Dev. Biol. 68: $96-109$

Weinzierl, R., J.M. Axton, A. Ghysen, and M. Akam. 1987. Ultrabithorax mutations in constant and variable regions of theprotein coding sequence. Genes Dev. 1: 386-397.

Wharton, K.A., K.M. Johansen, T. Xu, and S. Artavanis-Tsakonas. 1985. Nucleotide sequence from the neurogenic locus Notch implies a gene product that shares homology with proteins containing EGF-like repeats. Cell 43: 567581.

Wieschaus, E. and C. Nüsslein-Volhard. 1986. Looking at embryos. In Drosophila: A practical approach (ed. D. Roberts, pp. 199-227). IRL Press, Oxford.

Winslow, G.M., S. Hayashi, M. Krasnow, D.S. Hogness, and M.P. Scott. 1989. Transcriptional activation by the Antennapedia and fushi tarazu proteins in cultured Drosophila cells. Cell 57: 1017-1030. 


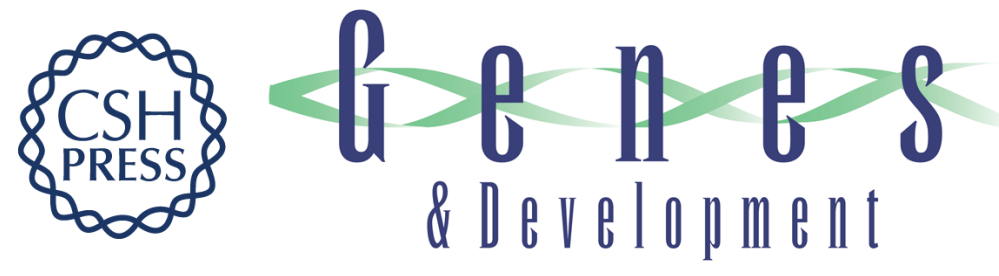

\section{Expression and embryonic function of empty spiracles: a Drosophila homeo box gene with two patterning functions on the anterior-posterior axis of the embryo.}

D Dalton, R Chadwick and W McGinnis

Genes Dev. 1989, 3:

Access the most recent version at doi:10.1101/gad.3.12a.1940

References This article cites 71 articles, 14 of which can be accessed free at:

http://genesdev.cshlp.org/content/3/12a/1940.full.html\#ref-list-1

License

Email Alerting

Service

Receive free email alerts when new articles cite this article - sign up in the box at the top right corner of the article or click here.

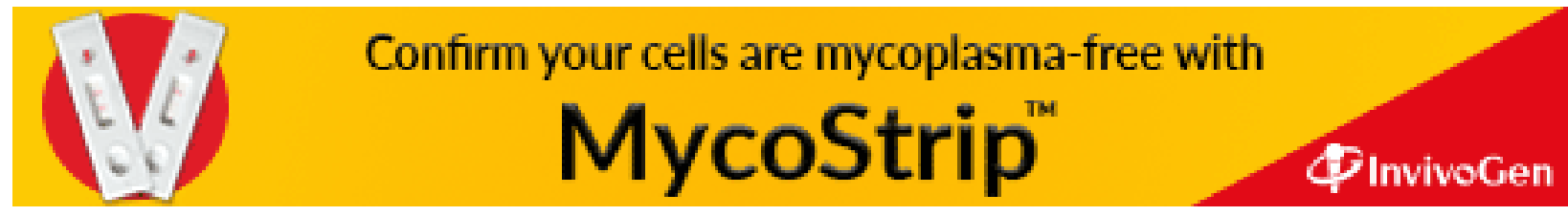

